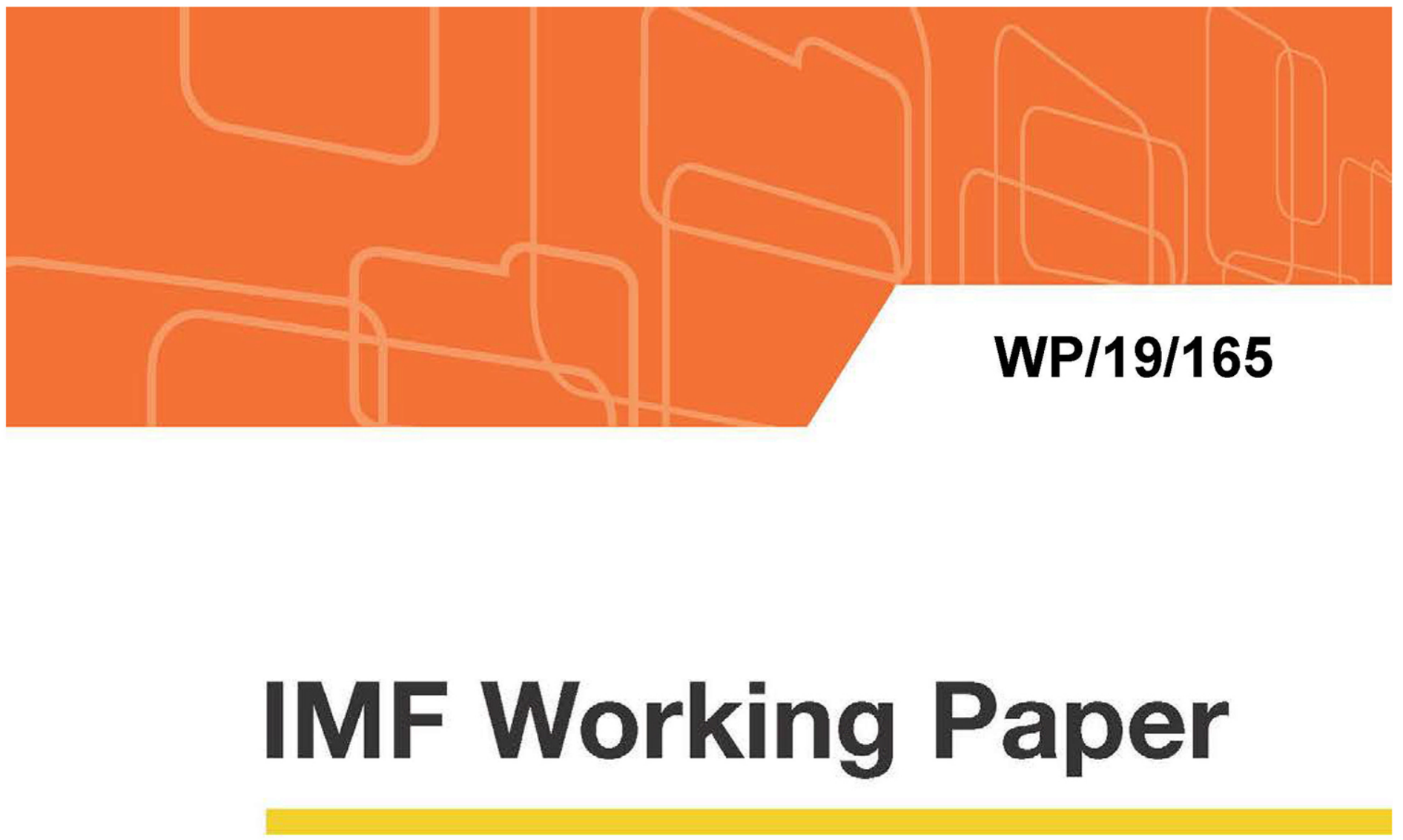

\title{
Statistical Coverage of Trade Finance - Fintechs and Supply Chain Financing
}

by Cornelia Lotte van Wersch

IMF Working Papers describe research in progress by the author(s) and are published to elicit comments and to encourage debate. The views expressed in IMF Working Papers are those of the author(s) and do not necessarily represent the views of the IMF, its Executive Board, or IMF management. 


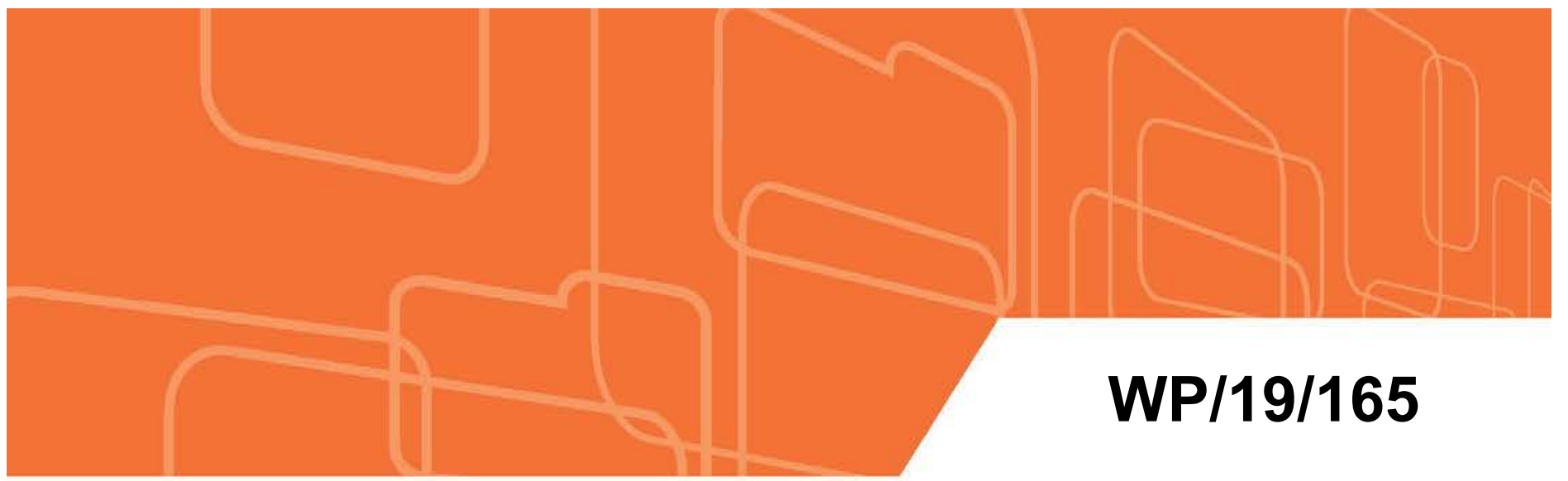

\section{IMF Working Paper}

\section{Statistical Coverage of Trade Finance - Fintechs and Supply Chain Financing}

by Cornelia Lotte van Wersch

IMF Working Papers describe research in progress by the author(s) and are published to elicit comments and to encourage debate. The views expressed in IMF Working Papers are those of the author(s) and do not necessarily represent the views of the IMF, its Executive Board, or IMF management. 


\title{
IMF Working Paper
}

Statistics Department

\section{Statistical Coverage of Trade Financing - Fintechs and Supply Chain Financing \\ Prepared by Cornelia Lotte van Wersch}

Authorized for distribution by Claudia Dziobek

July 2019

\section{IMF Working Papers describe research in progress by the author(s) and are published to elicit comments and to encourage debate. The views expressed in IMF Working Papers are those of the author(s) and do not necessarily represent the views of the IMF, its Executive Board, or IMF management.}

\begin{abstract}
Trade finance is the backbone of international trade for entities ranging from a small businesses to multi-national corporations. An estimated 80 percent of world trade relies on this form of finance (WTO, 2017). Despite its systemic importance and rapid growth, data availability is only partial. During the 2008 financial crisis, policy makers, notably the G20 recognized that the absence of comprehensive trade finance data posed a significant hurdle for policy-makers to make informed, timely decisions. This paper proposes a standalone dataset to reflect the scope, dynamic and recent innovations of the trade finance market to support macroeconomic policy analysis.
\end{abstract}

JEL Classification Numbers: F1, F3, F4, F6, O3

Keywords: Global Value Chains, Fintechs, Trade Financing, Supply Chain Financing, Statistics, SNA, BPM, BOPCOM

Author's E-Mail Address: corneliavwersch@gmail.com 
Abstract .$\underline{2}$

I. Trade Finance Data to Support Macroeconomic Policy Analysis. .$\underline{4}$

II. The Changing Trade Finance Environment $\underline{8}$

A. Fintechs -New Players in the Trade Finance Market ............................................... $\frac{8}{8}$

B. Blockchain Technologies and Other Innovations ….............................................

C. Trade Finance Instruments to Manage Working Capital ........................................10

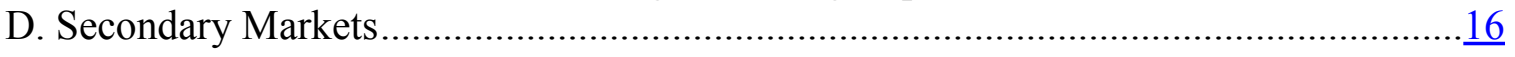

III. Macroeconomic Measures of Trade Finance ............................................................ 16

A. Capturing Trade Finance in the Macroeconomic Frameworks............................... 16

B. Compilation of a Satellite Table on Trade Finance..............................................18

C. The Indicators of the Satellite Table on Trade Finance …....................................... 19

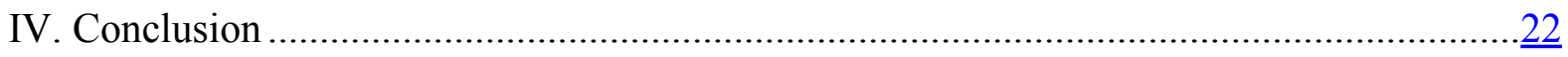

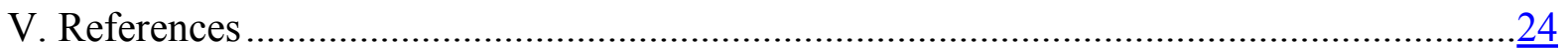

Tables

1. Proposed Satellite Table of Comprehensive Trade Financing (Liabilities of the Resident

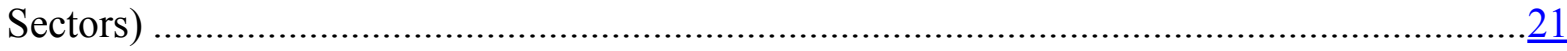

2. Derived Accounting for the Instruments to Finance Trade .........................................22

Figures

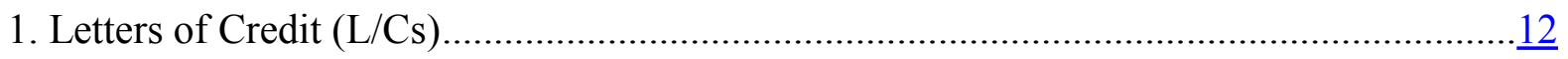

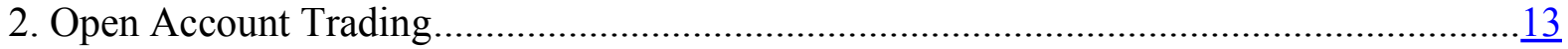

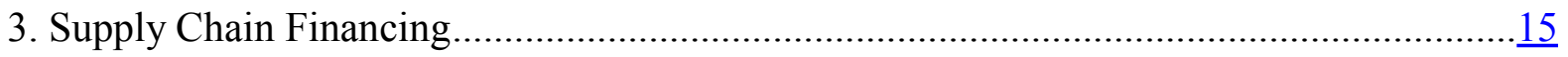

4. Most Used Instruments in Traditional Trade and Supply Chain Finance..........................17

\section{Box}

1. Working Capital is the Starting Point for Trade Financing …....................................10

\section{Annex}

I. New Supply Chain Finance (SCF) Instruments in More Detail ......................................27

\section{Annex Tables}

1. Receivables Discounting................................................................................... 28

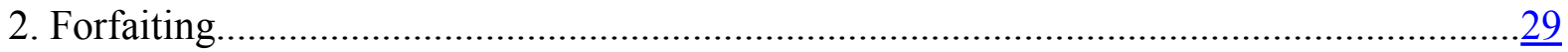

4. Approved Payables Finance................................................................................... 31

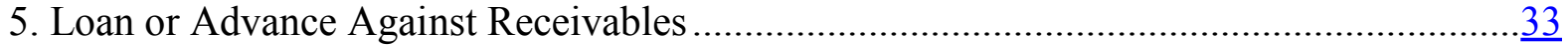

6. Loan/Advance Against Inventory ......................................................................... 34

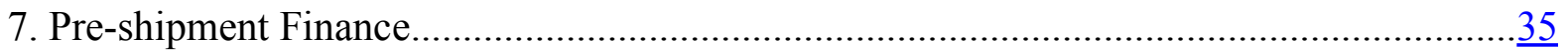




\title{
I. Trade Finance Data to Support Macroeconomic Policy Analysis ${ }^{1}$
}

\begin{abstract}
About 80 percent of international trade is financed by some form of trade credit (WTO 2017) most of which is short term and thus vulnerable to shocks. ${ }^{2}$ The turmoil of financial markets during the 2008-09 Global Financial Crisis led the international community to swiftly orchestrate a large-scale $\$ 250$ billion trade finance program to channel liquidity via the banking sector into the real economy. While the banking sector is an important provider of trade finance, a growing share of trade finance takes place through interfirm, open account trading. ${ }^{3}$
\end{abstract}

\section{Trade finance is an umbrella term encompassing a range of financial products that} companies utilize to bridge their trade cycle funding gap between paying suppliers and buyers. Suppliers, on the other hand, require a timely funding to pay for material and labor. Trade finance acts as an intermediary to manage payment and supply risks, while providing the supplier with accelerated receivables and the buyer with extended credit. Large multinational banks with specialized trade finance divisions, local commercial banks, and non-bank lenders with exclusive focus on trade finance are active in this market. ${ }^{4}$

\section{For policy analysis a global stand-alone dataset on the level of outstanding trade finance, its terms, and the main providers is needed. Comprehensive data on international trade finance are not available. It should cover whether the targeted interventions were adequate and effective in filling the gap. The March 2009, the G20 summit noted that “...the lack of a comprehensive international dataset for trade finance during the crisis has been a}

\footnotetext{
${ }^{1}$ I would like to thank Paul Austin, Malik Bani Hani, Claudia Dziobek, and Gabriel Quiros-Ramos for their valuable comments. Members of the IMF Balance of Payments Committee (BOPCOM) provided important input and some are participating in a pilot exercise. The author also gratefully acknowledges input from several international meetings; the Sixteenth Session of the Group of Experts on National Accounts of the Economic Commission for Europe (UNECE) Conference of European Statisticians in Geneva in 2017, the 11th meeting of the Advisory Expert Group on National Accounts (AEG), the $3^{\text {rd }}$ meeting of the UN Expert Group on International Trade and Economic Globalization Statistics in Luxembourg, and the OECD Working Parties of National Accounts and Financial Accounts meetings in 2017. Tesat Spacecom (Germany), Tempel (USA), the Chilean Economic Development Agency, and InvestChile generously shared experiences in a series of interviews conducted for this paper. Hendrik Tillmann-Zorn and Thorsten Ullrich created the figures which are based on Global Supply Chain Finance Forum (GSCFF).

${ }^{2}$ Chaffour, J.P. and M. Malouche (Eds). "Trade Finance during the Great Trade Collapse: Key Takeaways." The World Bank. 2011; World Trade Organization. 2017. https://www.wto.org/english/thewto_e/coher_e/tr_finance e.htm.

${ }^{3}$ The March 2009 G20 summit committed \$250 billion to support mainly larger banks, while the IFC and regional development banks targeted smaller banks and banks in developing countries. In 2017, multilateral banks supported cross border trade finance with $\$ 30$ billion. However, the International Chamber of Commerce (2018), BIS (2014) estimated that bank-guaranteed trade finance accounts for ten to thirty percent, while the remainder is organized by inter-firm trade credits through open account trading.

${ }^{4}$ Trade finance instruments offered by government-backed institutions are not covered in this paper.
} 
significant and avoidable hurdle for policy-makers to make informed, timely decisions. " 5 This paper lays out a template to collect comprehensive data to help clarify the important linkage between trade finance and the real economy.

Data should reflect the important innovations in the trade finance market. Trade finance markets have undergone significant innovation following growing international supply chain arrangements and increasingly globalized production patterns. Appropriate data templates must take into account the new environment. For example, global sourcing strategies employed by large multinational companies have given small and medium-sized companies (SMEs) new roles in global trade as third-party suppliers, producers, and distributers. ${ }^{6}$

\section{While traditionally, SMEs were active mainly in their domestic markets, they have} evolved to a key component in today's fragmented supply chains. The integration of the physical and the financial supply chains into global value chains (GVCs) have changed the dynamics of trade finance. While international trade finance was traditionally provided mainly by large banks to their large multinational clients, there are now many more providers and more borrowers in the trade finance market. Structural changes to the trade finance market occurred already before the 2008 crisis. GVCs have to a large part phased out bankintermediated Letters of credit (L/Cs) and moved to inter-firm open account trading, often supplemented by third-party financing of suppliers.

\section{Trade finance data should cover the full range of trade credit suppliers and} instruments. Fintechs are important new players providing Supply Chain Finance (SCF). They are innovative financial technology companies that develop new products catering to the needs of SMEs. With digital interfaces and electronic invoice systems, Fintechs compete with traditional trade finance providers, mainly banks. In contrast to bank-intermediated financing, SCF solutions offered by Fintechs build on inter-firm open account trading and enable the suppliers to raise finance based on the credit-rating of the company at the head of the supply chain, while the early payment is bridged by a third-party. A Fintech SCF uses an online portal and accounting software to streamline working capital access to the entire

\footnotetext{
${ }^{5}$ See G20 Trade Finance Experts Group. April Report Canada-Korea Chair's Recommendations for Finance Ministers. 2010.

${ }^{6}$ Multinational companies' (MNCs) global sourcing strategies of intermediary components and services are well documented in the literature. The location of the different stages in the value chain and the extent of control the MNC exerts over those stages are key decisions when companies break up the production processes across countries (offshoring). The strategy of "offshoring outsourcing" - the transfer of activities and processes to unaffiliated parties - is described in the literature as an outsourcing revolution. Companies are turning fixed into variable costs towards more broadly leveraging external resources, skills, and knowledge, and gaining operational flexibility in highly competitive environments. See Jain, J., G. Agarwal, G.S. Dangayach, and S. Banerjee, "Supply Chain Management: Literature Review and Some Issues," Journal of Studies on Manufacturing Vol.1-2010/Iss.1, (January 16, 2010): 11-25. / Boddin, D/ "The Role of Newly Industrialized Economies in Global Value Chains," IMF Working Paper WP/16/207.
} 
supply chain. Fintechs could qualify as money-creating intermediaries providing loans to goods suppliers and use securitization markets to raise trade finance capital.

\section{Data specifically distinguishing SMEs that are part of direct investment (DI) relationships ${ }^{7}$ from SME's at arm's-length are helpful for analysis. SMEs operating} within the boundary of DI typically have access to internal capital markets where much of this trade is financed through intra company netting and internal funding, including access to retained earnings, or commercial papers. Many larger firms are also able to set up in-house banks to finance various subsidiary trading. Parent companies may finance the affiliated SME via equity or debt depending on a variety of factors such as corporate taxation rules in the parent and the SME economies.

\section{In contrast, $S M E s$ in at arm's-length relationships are more vulnerable to liquidity} constraints than their peers within a DI boundary. For traditional lenders, the financing of SMEs may be too complex and too low scale to be serviced. Following the financial crisis many banks reduced their exposure to smaller businesses. ${ }^{8}$ Nevertheless, trading in intermediate goods within global value chains has grown in emerging markets. Integration of trade finance and value chains to promote the participation of SMEs in the global economy, is therefore seen as important building block towards economic growth. ${ }^{9}$

\section{Financial disruptions at the level of a supplier can have ripple effects throughout the} entire value chain. Upstream companies are vulnerable to the risks and resilience of SMEs in their supply chains, as critical product components are often sourced from SMEs worldwide. The financial decision of an upstream company can impact the financial situation and the performance of downstream suppliers and possibly suppliers' suppliers in arm's

\footnotetext{
${ }^{7}$ IMF BPM6 paragraph 6.9-6.10: A direct investment relationship arises when an investor resident in one economy makes an investment that gives control or a significant degree of influence on the management of an enterprise that is resident in another economy. [...] Enterprises in a direct investment relationship with each other are called affiliates or affiliated enterprises. 6.10 Because there is control or a significant degree of influence, direct investment tends to have different motivations and to behave in different ways from other forms of investment. As well as equity (which is associated with voting power), the direct investor may also supply other types of finance, as well as knowhow.

${ }^{8}$ In the International Chamber of Commerce's (ICC) 2016 trade survey, 90 percent of respondents said that the complexity of compliance was the chief barrier to the provision of trade finance. (https://iccwbo.org/publication/icc-global-survey-trade-finance-2016/). See also Blancher, N., Appendino, et. Al Financial Inclusion of Small and Medium-Sized Enterprises in the Middle East and Central Asia, IMF Departmental Paper Series, IMF. 2019.

${ }^{9}$ Brandi, C. and B. Schmitz, "Financing Global Development: The Potential of Trade Finance." German Development Institute, Germany, 2015. https:/www.die-gdi.de/en/briefing-paper/article/financing-globaldevelopment-the-potential-of-trade-finance.
} 
length relationships. The experience of the 2008 financial crisis highlighted that this can affect the supply chain as a whole. ${ }^{10}$

Data on trade finance should be consistent across macroeconomic datasets to support policy analysis. Trade finance data should support early warning analysis of possible liquidity crunches and support analysis of the links between global trade, investment, and GDP growth. It is, therefore, important that the concepts and definitions of the dataset on trade finance are consistent with those of other macroeconomic indicators. The dataset proposed in this paper builds on the main macroeconomic statistical manuals such as the System of National Accounts 2008 (2008 SNA), the Balance of Payments and International Investment Position Manual, $\sigma^{\text {th }}$ edition (BPM6), the Government Finance Statistics Manual 2014 (GFSM2014), the Monetary and Financial Statistics Manual and Compilation Guide (MFSMCG), and the External Debt Statistics Guide for Compilers and Users (2013 EDS). ${ }^{11}$

The development of a dataset on trade finance can be accomplished as a coordinated effort of international organizations such as the IMF, World Bank, WTO, OECD, and others, and with their member countries. The data template presented in this paper was discussed in the IMF's Balance of Payments Committee (BOPCOM) meetings in 2017 and in 2018 and three countries volunteered to provide experimental data and review the feasibility of the template. To capture evolving market structures and "ensure that macroeconomic statistics mirror global realities and maintain policy relevance," 12 the G20 recommended that "multilateral agencies coordinate and establish a comprehensive and regular collection of trade credit in a systematic fashion."

\section{The proposed table seeks information on the main players (financial corporations} (FCs), non-financial corporations (NFCs) including Fintechs), and instruments (open account, SCF, and traditional trade finance). Section II describes the new providers of trade finance and instruments and Annex I contains more detailed guidance for data compilers. Section III includes the proposed template and the underlying accounting.

\footnotetext{
${ }^{10}$ Large companies such as BASF, BMW, and Hewlett Packard, provided unprecedented financial support to suppliers during and after the 2008 crisis in order not to destabilize their supply chain. See Sheffi, Y. Lessons of a Crisis. Building Strength from Supply Chain Independence. 2017.

https://c2fo.com/resources/enterprise/lessons-crisis-yossi-sheffi/

${ }^{11}$ United Nations. System of National Accounts 2008. 2009.; International Monetary Fund. Balance of Payments and International Investment Position Manual 6th Edition. footnote to paragraph 5.72, and paragraphs 6.9-6.10. Washington D.C., 2009.; IMF. Government Finance Statistics Manual 2014: Manual. Washington, D.C., 2014.; IMF. Monetary and Financial Statistics Manual and Compilation Guide. Washington D.C., 2016. IMF.

"Further External Debt Accounting Principles." In External Debt Statistics: Guide for Compilers and Users, Chapter 6. Washington D.C. 2014. http://www.tffs.org/pdf/edsg/ft2014.pdf

${ }^{12}$ IMF Balance of Payments Committee Annual Report (2016).
} 


\section{The Changing Trade Finance Environment}

\section{A. Fintechs-New Players in the Trade Finance Market}

\section{Fintechs have become important new players in the fast-changing trade finance}

market. ${ }^{13}$ Fintechs are (non-bank) institutions that use digitized technologies to provide trade finance. They also provide some services similar to traditional banking activities but are currently not subject to bank regulations, transparency, consumer protection, or capital requirements. Fintechs provide financial support to SMEs, especially in developing countries, specializing in risk-assessment and evaluation models not typically serviced by banks. Fintech companies that operate in trade finance focus on cost-reduction initiatives such as automation, and concentrate on mid-tier, and non-listed companies, while large financial institutions in this market provide service to established customers and large multinational companies. Fintechs open new channels for SME financing and facilitate greater SME financial inclusion. ${ }^{14}$

Fintechs use big data and cloud-based technology. They offer old products in a new appearance, as well as new services in trade finance, marketplace lenders, micro-lending, and "robo-investment platforms." Fintechs set themselves apart from traditional finance providers by employing technical platforms that compete in terms of efficiency, security, and userfriendliness for buyers and for suppliers. Services such as onboarding new suppliers, and overall managing buyers-supplies relationships in addition to freeing up cash in the supply chain give Fintechs in the trade-financing markets the additional edge.

"Fintegration" is a term used to describe a collaboration of Fintechs and banks. The International Chamber of Commerce (ICC) noted in its Global Survey on Trade Finance 2017 report, that "Fintechs now count major financial institutions among their shareholders, thus effectively turning those Fintechs into an asset rather than a competitive threat."

\footnotetext{
${ }^{13}$ He, D., R. Leckow, et al. "Fintech and Financial Services: Initial Considerations." Staff Discussion Note 17/05, International Monetary Fund, Washington, DC. 2017. The Financial Stability Board (FSB) defines Fintech as "Technologically-enabled financial innovation that could result in new business models, applications, processes or products with an associated material effect on financial markets, financial institutions and the provision of financial services" FSB, FinTech Credit: Market Structure, Business Models and Financial Stability Implications. 2017.

${ }^{14}$ The Report "The Future of FinTech: A Paradigm Shift in Small Business Finance", presented at the World Economic Forum 2015, notes: "Innovation, through what has been called FinTech, is already disrupting the ways financial services are being offered, promising to provide access to underserved markets in new ways." Roger, D., R. Leuschner, T. Y. Choi. "The Rise of FinTech in Supply Chains" Harvard Business Review. 2016. note that large companies, including Apple, Dell, and P\&G are using FinTech companies to gain access to funds within their supply chains, "using the capital to better their businesses."
} 
According to a survey by the Accenture Fintech Innovation Lab, and depending on the market segment, Fintechs increasingly see themselves as partners to financial institutions. ${ }^{15}$

\section{B. Blockchain Technologies and Other Innovations}

Fintechs build the infrastructure that connects different players in the trade ecosystem. Traditionally, trade finance was a manual and paper-intensive function in the financialservices industry. Blockchain and smart contracts are considered a "game changer technology that can transform trade finance processes. ${ }^{16}$

\section{Blockchain addresses efficiency and transparency challenges that limited the access to} trade finance for SMEs. It can be used as a digital ledger to record and verify transactions to facilitate 'tracking and tracing' across multiple actors. While traditional trade finance requires each participant to maintain its own administration and databases, Blockchain integrates all the necessary information in one digital document. Transactions, their authenticity and state of fulfilment can be monitored by all parties at any given time. Blockchains maintain secure digital records, improve the traceability along the supply chain, trace change of ownership changes, and unlock payments. ${ }^{17}$

\section{"Smart contracts" built with blockchain technology specifically for trade finance support more efficient processes and data recording. Smart contracts are self-operating} computer programs that automatically execute when triggering events take place (e.g., a scanned arrival code of goods, or an expiration date is met). The "events" are agreed upon by the parties and coded in software for execution. These technologies have the potential to replace established processes that rely on verification procedures by correspondent banks, involve manual and time-consuming documentary evidence and coordination efforts. Tech companies, global banks, credit insurers, and logistic providers around the world are engaged in various proof of concepts operations and pilot projects. ${ }^{18}$ The digital revolution combined with structural changes in the market spurs innovation, but it may take some time for the new solutions to become industrialized.

\footnotetext{
${ }^{15}$ ICC Rethinking Trade and Finance. 2017. https://iccwbo.org/publication/2017-rethinking-trade-finance/; Accenture (2018); Study by the Fintech Innovation Lab: Mind the Gap - Addressing Challenges to Fintech Adoption.

${ }^{16}$ See for instance: TradeIX https://tradeix.com/ Rewiring Trade and Working Capital Finance.

${ }^{17}$ See ModulTrade (2017): Whitepaper - Democratizing global trade with Blockchain technology.

${ }^{18}$ For example: The Marco Polo Trade Finance Initiative: https://www.marcopolo.finance engages with BNP Paribas, Commerzbank, ING, Standard Chartered, Microsoft, and various tech companies.
} 


\section{Trade Finance Instruments to Manage Working Capital}

Trade finance instruments are tools for companies to manage their working capital. Working capital is key for supply chain financing (see Box 1) and working capital management decisions have implications on supply chain business partners upstream and downstream within the network. ${ }^{19}$ The increase of fixed and working capital efficiency is also an important driver of shareholder value along with the reduction of operating costs, growth of revenue, and minimization of taxes. There is, therefore, a close relationship between a company's management of supply chain activities and its financial performance. While traditional instruments remain important, technological innovations have brought about new instruments.

\section{Traditional instruments}

Traditional Letters of Credit (L/C) (see Figure 1) have been used for hundreds of years and are typically offered by banks. This includes short-term pre-shipment trade loans and guarantees intermediated by banks between the exporter (supplier) and the importer (buyer). $\mathrm{L} / \mathrm{Cs}$ are predominantly buyer-centric instruments, where the bank of the buyer provides a guarantee to the supplier that it will be paid regardless of whether the buyer ultimately pays. Because there remains the risk that the issuing bank will not pay in the end, a bank in the supplier's country typically needs to confirm the L/C and thereby underwrites the payment. The risk that the buyer will fail to pay is hence transferred from the supplier to the issuer of the letter of credit. Because L/Cs are processed predominantly manually, and often still paper-based, they constitute a costly, complex, and labor-intense financial service. These disadvantages may have caused the shifts towards trade financing in "open account" relationships directly between buyers and suppliers without active intermediation long before the financial crisis. Nevertheless, L/Cs are a key tool to mitigate the risks of international trade for firms trading with high-risk destinations. ${ }^{20}$

\section{Box 1. Working Capital is the Starting Point for Trade Financing}

The working capital ratio (current assets/current liabilities) indicates whether a company has enough shortterm assets to cover its short-term debt. Balanced cash management in a business is essential because insufficient cash and no alternative funding means there are not enough funds to meet obligations such as buying raw materials or paying wages and overheads. Too much cash, on the other hand, means a company has idle funds for which it foregoes investment. Holding too much inventory has implications for the financial performance of a business in the form of costs for storage, handling, insurance, etc., and cash tied up that could

\footnotetext{
${ }^{19}$ See Sheffi, Y. 2017. notes "As the global economy remains prone to bullwhips and domino effect disruptions affecting both financial and physical supply chains [...] makes management of working capital across the supply chain as important today as in 2008 .

${ }^{20}$ SWIFT data in a study Niepmann and Schmidt-Eisenlohr (2013) show that about 91 percent of all L/Cs are used for cross-border transactions. L/Cs are used mainly to overcome a lack of trust due to distance, country risk and variations in legal requirements (commercial L/Cs and its subcategories). They are also useful for domestic transactions where buyer and seller do not have an established relationship.
} 
be used otherwise. The right balance is a trade-off between liquidity versus profitability. As illustrated in the diagram below, suppliers need to get paid as early as possible, while buyers want to pay as late as possible. When the cash collection of suppliers slows down, suppliers have limited practical alternatives. They can extend the credit line or take out short-term debt with their local bank; they can use the accounts receivable as collateral to raise cash; or extend their payables. Depending on the size, location, and credit-worthiness of the suppliers, only limited options may be available - if alternative financing is not feasible, they may need to slow down their business. The underlying friction between suppliers' and buyers' objectives was severely magnified during the 2008 financial crisis.

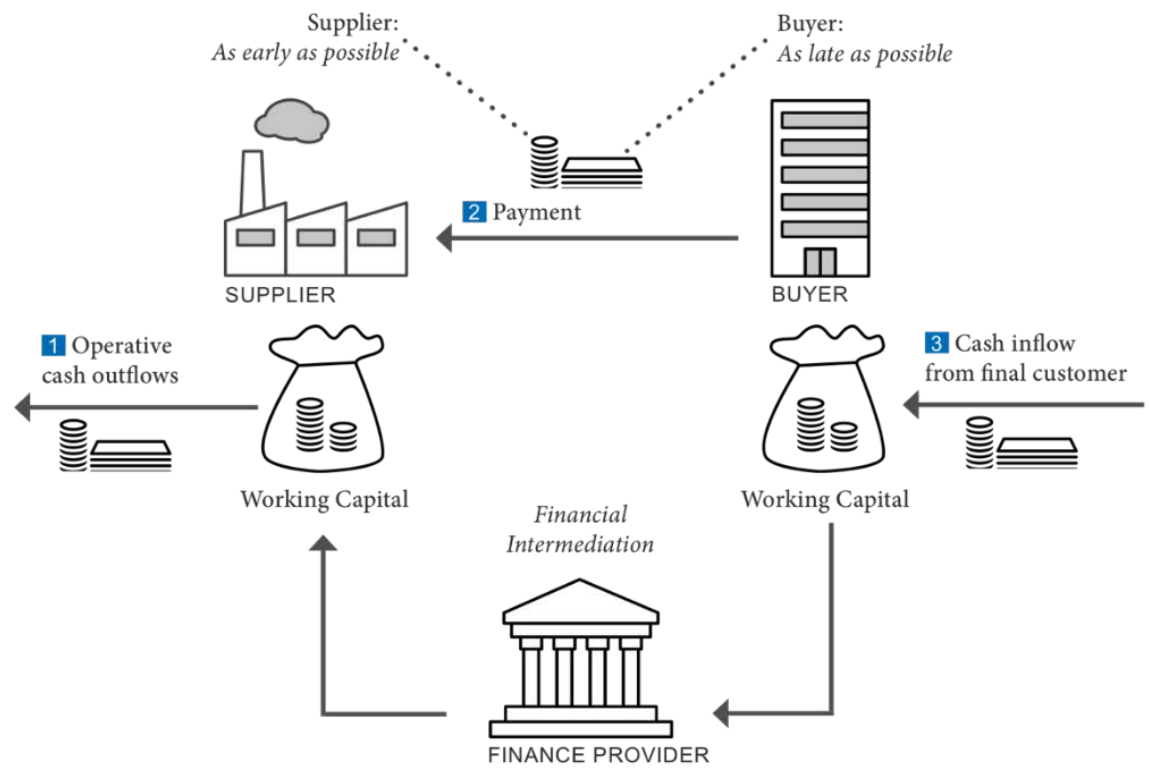

Source: IMF Staff.

From the perspective of the supplier, a weakness of $\mathrm{L} / \mathrm{Cs}$ financing is the very advanced point in time in the transaction cycle when financing is received, stretching the time between the buyers-initiated purchase order to the approved invoice. This can operationally be critical to suppliers depending on the length and complexity of the production cycle and the involvement of sub-suppliers and sub-contractors. Micro, small and medium-sized enterprises, especially in developing countries, are often faced with a mixture of structural constraints and are required to set aside large collaterals against trade loans or pay high fees. Long waiting times, the combination of costs with high coordination efforts, foreign currency risks and time restrictions, make L/Cs cumbersome especially for this group of enterprises. The availability of trade finance often depends on the extent to which the local banking sector is developed and internationally networked. ${ }^{21}$

${ }^{21}$ Brandi, C. and B. Schmitz, (2015). 
Figure 1. Letters of Credit (L/Cs)

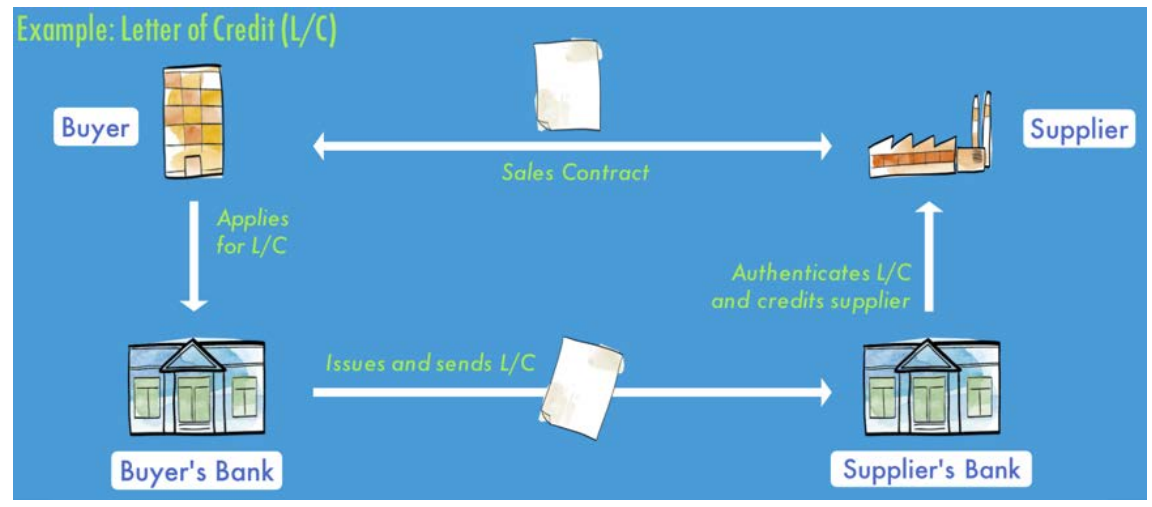

Source: IMF Staff.

Macroeconomic statistics capture trade credits and advances but do not cover $\mathrm{L} / \mathrm{Cs}$ and other short-term documentary credits or guarantees. L/Cs and other short-term preshipment trade loans and guarantees ensure payment for suppliers, on time and for the correct amount, before the actual change of ownership occurs and financial assets and liabilities are created. This is in contrast to trade credit and advances, when financial instruments are created concurrently with the change of ownership. Once the conditions of the $\mathrm{L} / \mathrm{C}$ are met, the supplier receives payment, and the buyer receives the documents needed to claim ownership. These off balance sheet instruments, outside the scope of macroeconomic statistics, may complement comprehensive trade finance statistics with an important indicator of bank-guaranteed trade.

\section{Open account trading}

Open account trading is the principal alternative to traditional bank trade finance. In open account trading, the buyer is directly responsible for meeting the payment obligation in relation to the underlying transaction (see Figure 2). This refers to inter-firm financing and may account for as much as $70-90$ percent of trade finance. ${ }^{22}$

\section{In open account trading, suppliers ship goods and documents directly to the buyer} before payment is due, making open account trading the buyers' most attractive option. Buyers typically may take 30,60 , or up to 120 days to settle the invoice. At the same time, it is the least secure option for suppliers who bear the non-payment risk and often more importantly a shortage in working capital. This form of financing was traditionally limited to companies with long-term and well-established commercial relationships, and for low-risk markets. Companies of all sizes now pursue open account trading as alternatives to

\footnotetext{
${ }^{22}$ BIS (2014) and the Global Supply Chain Finance Forum (GSCFF) Standard Definitions for Techniques of Supply Chain Finance (2019) http://supplychainfinanceforum.org/ provide some estimates about the composition of the trade finance market.
} 
traditional instruments and some estimates suggest that open account trading has significantly outpaced L/C.

Figure 2. Open Account Trading

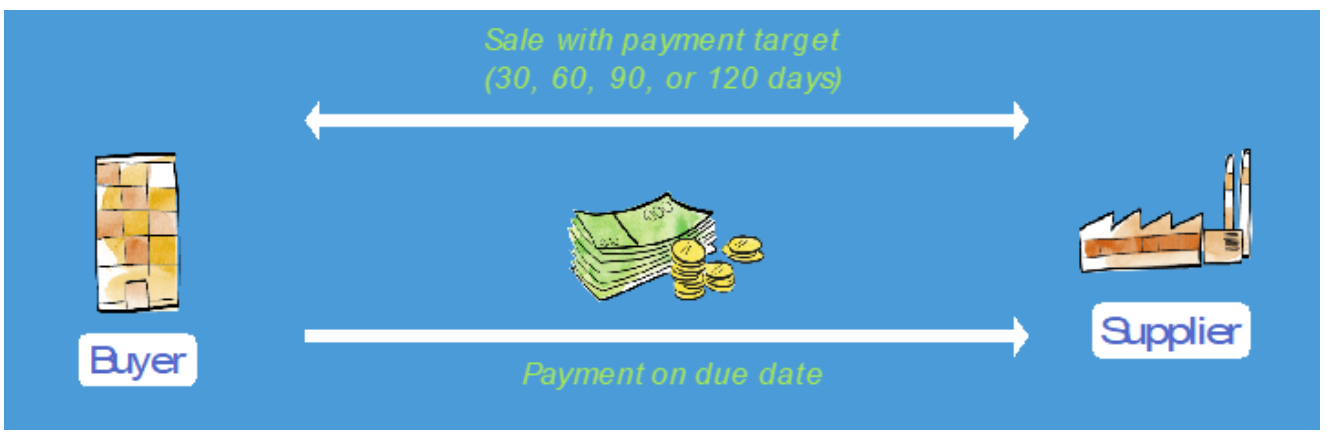

Source: IMF Staff.

Open account trading can magnify the inherent problem of opposing interests that buyers and suppliers have regarding cash flow management. Buyers' interest to maintain cash reserves frequently forces downstream suppliers to extend payment terms up to, in some cases, 120 days or pass on early payments discounts to cash-rich buyers. Suppliers, often SMEs, in turn, need to take out costly loans or export credit insurance provided by public export credit agencies or private insurance firms to bridge the gap or cover the risk. Eligible exporters can buy products offered by banks that provide bilateral working capital financing, such as pre-export finance, supplier credits, receivables discounting, or forfaiting. Rejected trade finance requests from SMEs, and the global financial and economic crisis, exposed an incomplete trade finance market with demand exceeding supply, alarming new businesses, market observants and political leaders. ${ }^{23}$ Open account trading has thus become the main starting point for new supply chain financing products.

\section{New Supply Chain Financing (SCF) Solutions}

SCF solutions refer to instruments allowing the largest company of a supply chain to use its superior credit rating to give its lower-rated suppliers access to financing at more favorable rates than they would obtain otherwise. Benefits include lengthening payment terms for buyers and shortening them for suppliers, thus improving working capital for both. New SCF solutions are offered by SCF providers (Fintechs) or directly by banks that have SCF in their service portfolio. The Global SCF Forum ${ }^{24}$ defines SCF as the "use of

\footnotetext{
${ }^{23}$ See: ICC. 2017. which notes that "Fintechs, many in startup phase, have identified significant opportunities in the financing of international trade, and have the potential to play an important role ... [to] close, the global trade finance gap [of $\$ 1.6$ trillion] because it is increasingly clear that banks will be unable to materially do so."

${ }^{24}$ The main partners in the Global SCF Forum are The International Chamber of Commerce (ICC) Banking Commission, BAFT, the Euro Banking Association (EBA), Factors Chain International (FCI), and the
} 
financing and risk mitigation practices and techniques to optimize the management of working capital and liquidity invested in supply chain processes and transactions". A narrower definition is provided by a prominent Fintech: "Supply chain finance is a set of solutions that optimizes cash flow by allowing businesses to lengthen their payment terms to their suppliers while providing the option for their large and SME suppliers to get paid early (Primerevenue.com)". This paper uses the standard definitions of the Global SCF, as described more in detail in Annex I.

SCF is enabled through integrated technology platforms - SCF portals- that make it possible to extend payment terms to buyers while accelerating payment to suppliers (see Figure 3). Suppliers of all sizes upload their invoices directly to the portal or send their invoice using specific accounting software. The buyer approves the invoice for early payment by the SCF provider and the full invoice amount less a financing fee is transferred to the supplier's bank account. At maturity of the invoice period (with or without extension), the buyer will pay the due amount directly to the finance provider (if the supplier has sold the invoice) or to the supplier's bank account (if the supplier has not sold the invoice). Overall, however, buyers only arrange the financing that allows suppliers to get early payment. Buyers can be of all sizes, once an established buyer-finance/SCF provider relationship exists. SCF concepts include a wide range of sophisticated instruments, techniques, and IT solutions that comprise traditional instruments in digitized formats and new services altogether. ${ }^{25}$

\section{Programs are connected with multi-funding sources to deal with multiple currencies and jurisdictions as well as to work with non-investment-grade or unrated companies. Globally operating banks see SCF as an important new area of their activity and focal point of current research and development. It is expected that the Internet of Things (IoT) and smart contracts will allow real-time tracking of goods which could become a powerful big data source for real-time data.}

\section{In developing economies, supply chain financing could enable financial intermediaries to provide funding to SMEs without having to accept their risk, basing the risk} assessment on the creditworthiness of the onboarding buyers. The African Development

\footnotetext{
International Trade and Forfaiting Association (ITFA). In 2016, the Global SCF Forum published Standard Definitions for Techniques of Supply Chain Finance. The document aims at removing current inconsistencies in terminology and promoting the global adoption of the suggested terminology (www.supplychainfinanceforum.org).

${ }^{25}$ Respondents to the ICC 2018 Global Survey on Trade Finance estimated that they processed about $\$ 9$ trillion global value of trade finance transactions during 2017, and 43 percent of respondents said that SCF rose in 2017 compared to traditional techniques. In the Americas, the (bank-implemented) proportion of SCF is somewhat higher than in other regions, with payables finance being one of the dominating instruments. Respondent banks with the largest value of trade finance, reported the biggest rise in SCF. Implementing SCF requires technical competency and access to enabling platforms and technologies.
} 
Bank estimated that Africa has an unmet demand for trade finance of more than US\$90bn and Asia of $\$ 425 \mathrm{bn}$ annually. ${ }^{26}$

Figure 3. Supply Chain Financing

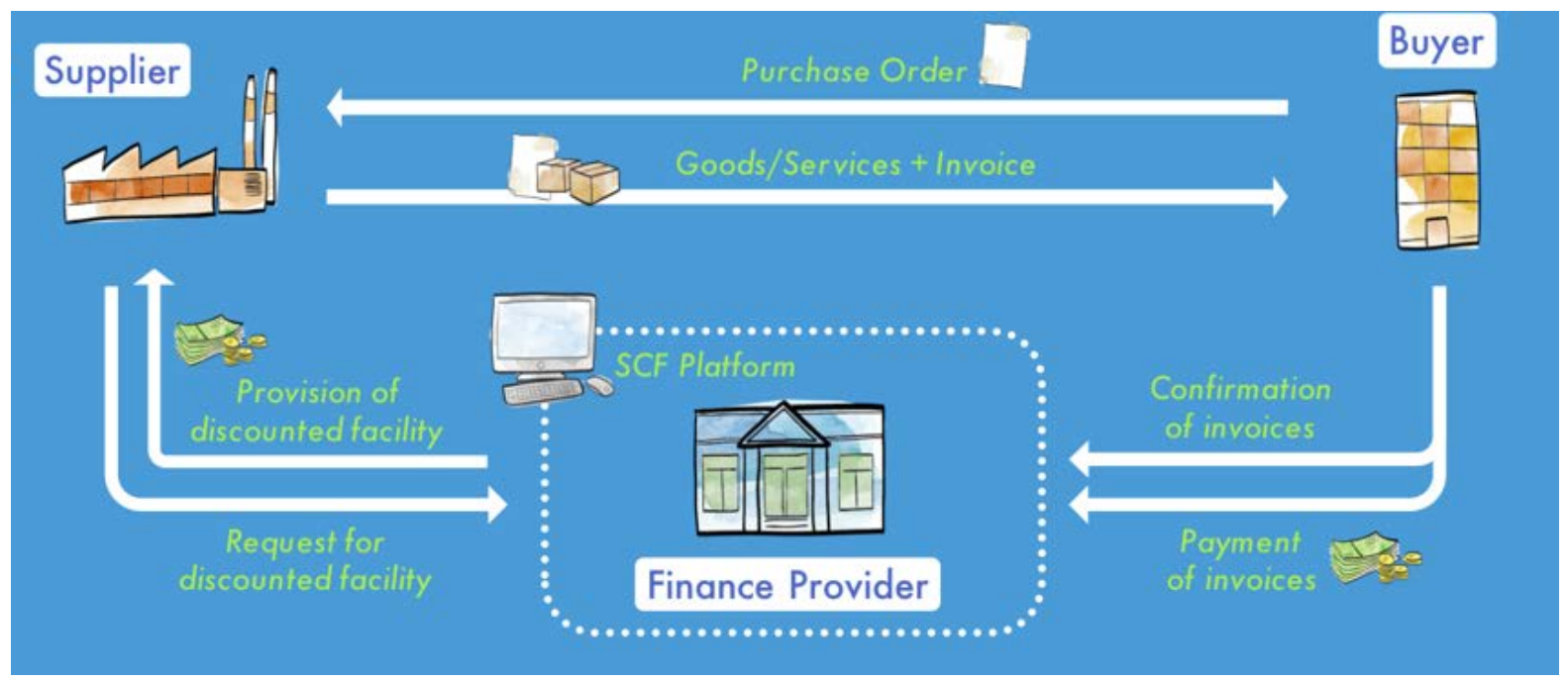

Source: IMF Staff.

In the categories of Approved Payables/Receivables Financing, the financial claims move from the suppliers' books to the SCF provider. The SCF provider takes full legal and economic ownership rather than a security interest in the collateral. In return, it provides the supplier with advance payments less the financial service charge (called discount), reducing the "days sales outstanding" to provide the supplier with liquidity and working capital. SCF providers argue that the main attraction is that no additional debt creation is involved on either side (supplier or buyer) — only an extension of payables for the buyer and a true sale of receivables by the supplier. Other than the traditional factoring that would only include the bilateral relationship between supplier and finance provider, the SCF comprises all parties to the transactions with the SCF as facilitator using the buyer's creditworthiness and digitization as cost advantage.

The other SCF category is based on instruments where loans and advances are provided in return for rights to a collateral, and the loan is recorded as a liability in the beneficiary's balance sheet. The suppliers repay the loans upon maturity and interest on an accrual basis. Special cases are (i) loan or advances against inventory - an asset-based financing instrument where the finance provider obtains title over the goods as collateral (e.g., Finetrading); (ii) inventory repurchase (repo) agreements, or buy-back agreements where the buyer/supplier temporarily "sells" its inventory to a financing entity, and "buys' it back after a predetermined time; however, the inventory stays on the balance sheet and the

\footnotetext{
${ }^{26}$ See African Development Bank. Second Trade Finance in Africa Survey Report: Trade Finance in Africa: Overcoming Challenges. Cote D'Ivoire. 2017.
} 
funds received are recorded as liability until the repurchase takes place within the pre-agreed upon period.

Finetrading, in contrast, is not considered a financial transaction because the Finetrader acquires the goods and not the claim. Finetrading combines 'Finance' and 'Trading' especially by SMEs. The Finetrader takes ownership and pre-finances the goods on behalf of the buyer for a defined financing period. For the buyer, the benefits are reduced inventory and improved working capital, while the supplier gets paid immediately. Finetrading is a trade finance tool typically provided by intermediaries other than banks.

\section{Secondary Markets}

Fintechs also access the securitization markets as an additional way of financing SMEs. The issue of securities backed by trade receivables came almost to a stand-still during the global financial crisis. ${ }^{27}$ Participating SMEs can utilize the technology platform provided by Fintechs to sell their trade receivables held against their customers. As intermediaries, Fintechs select and structure eligible receivables, and match them with investors. Because of the difficulties SMEs often face with obtaining credit through regular channels, securitization (in addition to SCF) could enhance the financial base by enabling risk-transfer from banks to a wider pool of investors beyond the banking sector. Depending on the size of the market, SCF and securitization may also contribute to a decrease in financial stability.

\section{Macroeconomic Measures of Trade Finance}

\section{A. Capturing Trade Finance in the Macroeconomic Frameworks}

Currently, there is no comprehensive global dataset separately covering trade finance statistics. The three broad categories of financial assets and liabilities recognized in the statistical methodological manuals are equity and investment fund shares, debt instruments, and other financial assets and liabilities. In addition, the 2008 SNA and BPM6 use a more detailed classification that is based on legal characteristics that describe the form of the underlying relationship between the parties to an instrument and are also related to their liquidity and economic purpose. However, trade finance encompasses a wider range of instruments at the financiers' disposal (see Figure 4) - these financial instruments require additional breakdowns to the standard financial account classifications and components.

\footnotetext{
27 Trade receivables securitizations allow banks or non-banks to raise capital by selling a selection of receivables (non-tradable financial assets) to a legally separate special purpose vehicle ('SPV'); based on the acquired receivables, the SPV can issue collateralized notes or commercial paper with the issuance proceeds flowing back to the original selling company. Because SPVs are separate entities, securitization can typically lead to a rating higher than the company's own credit rating, thereby providing access to greater liquidity at a lower cost of funds.
} 
Traditional $\mathrm{L} / \mathrm{Cs}$ are not included in the macroeconomic statistics because they are considered contingent instruments, therefore off-balance sheet and not recorded as financial assets. Therefore, extensions are required to the current macro-statistical frameworks to facilitate an accurate measurement of domestic and cross-border trade finance.

\section{Figure 4. Most Used Instruments in Traditional Trade and Supply Chain Finance}

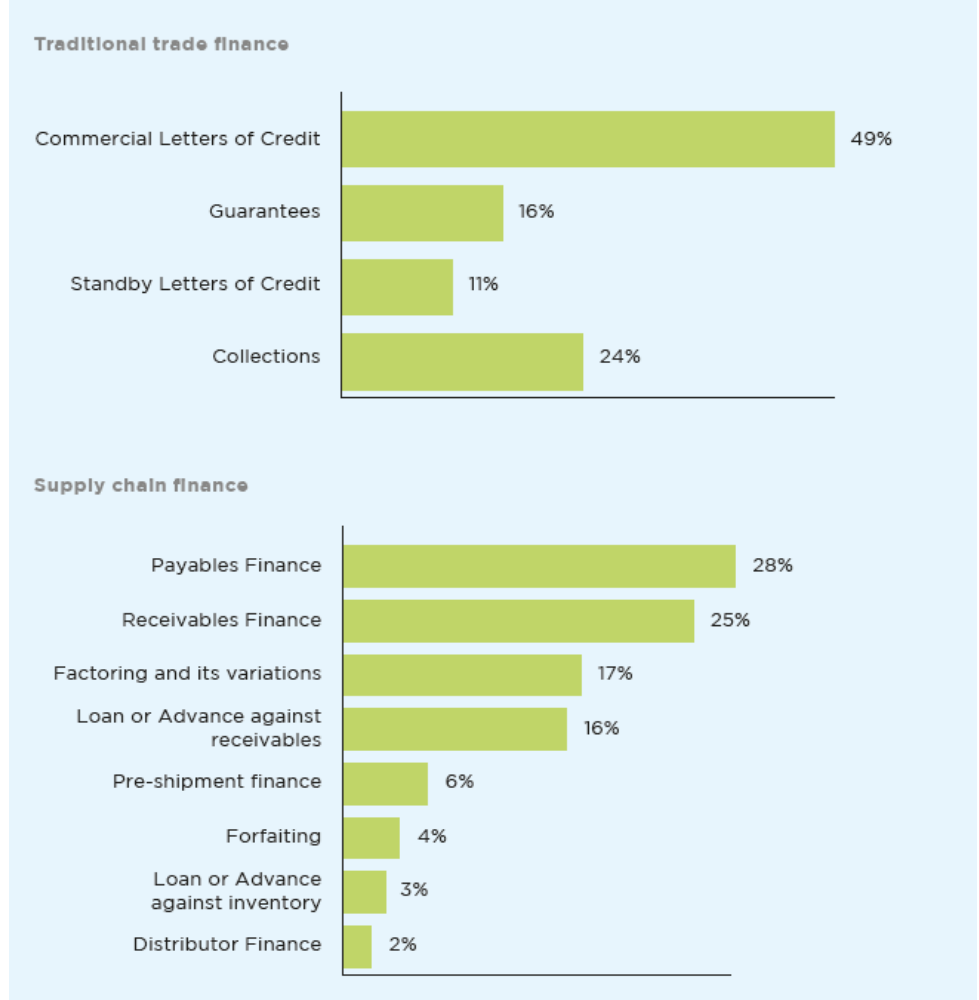

Source: ICC Global Survey on Trade Finance 2018.

\section{In external sector statistics, national accounts, and financial statistics, transactions linked to trade financing are short-term instruments recorded as follows. ${ }^{28}$}

- Trade credits and advances: record trade finance obtained through open accounts or cashin-advance directly between the exporter and the importer; these do not include loans to finance trade credit, which are classified as loans

- Loans-short-term: include loans to finance trade obtained from banks or other non-bank financial institutions not in the form of securities

\footnotetext{
${ }^{28}$ Export credit guarantees offered by governments or export-import banks (public deposit-taking corporations) are discussed in the Government Finance Statistics Manual (GFSM 2014). These are beyond the scope of this paper, but may well be part of a future comprehensive data collection on trade financing.
} 
- Debt securities - short-term: refer to bankers' acceptances that are eligible for rediscounting in a secondary bankers' acceptance market are usually classified as debt securities, ${ }^{29}$ and

- Direct investment in external sector statistics- debt instruments: includes trade finance extended between affiliated companies.

\section{In the macroeconomic statistics, apart from trade credits and advances, other} instruments do not require a breakdown to separately identify transactions/positions linked to trade financing. The standard component of trade credits and advances covers only credit extended directly by the suppliers of goods to their customers. Other trade-financing categories, such as any working capital related financing provided by third parties/financial intermediaries, traditional bank-intermediated techniques, or newer supply chain financing instruments are not separately distinguished or at all captured. Further, trade credits and advances are often not directly measured, but rather approximated using estimation techniques or calculated as a residual item. The standard components of other investment in external sector statistics, for instance, are classified by institutional sector, and in principle, by original maturity and currency composition. ${ }^{30}$ These attributes provide a sound base for assessing liquidity or solvency affecting a specific sector and facilitate broader analysis of exchange rate and reserve management policy options - but with a missing link to trade. ${ }^{31}$

\section{B. Compilation of a Satellite Table on Trade Finance}

\section{The G20 acknowledged that international statistics produce insufficient data on trade finance and asked to "coordinate and establish a comprehensive and regular collection of trade credit in a systematic fashion." At its 2017 meeting, the BOPCOM supported the idea of developing a proposal for collecting trade finance information for discussion at the 2018 Committee meeting. ${ }^{32}$ Trade finance instruments currently included in macroeconomic statistics are spread over different functional categories, are combined with other instruments, and often are only proxied or imputed in data compilation. No separate}

\footnotetext{
${ }^{29}$ See IMF MFSMCG paragraph 4.99: Acceptances ineligible for rediscounting are designated as other acceptances and are classified as loans or trade credit depending on the nature of the acceptance.

${ }^{30}$ Details of currency composition and remaining maturity are included for selected position data in memorandum and supplementary tables to external sector statistics (BPM6 Appendix 9).

${ }^{31}$ The broader concept of trade-related credit is mentioned in a footnote to BPM6 5.72: Trade-related credit is identified as a concept in External Debt Statistics: Guide for Compilers and Users 2013, Chapter 6, Further External Debt Accounting Principles. It consists of trade credit as well as trade bills and credit provided by third parties to finance trade. It should be compiled as a supplementary item, where significant.

32 See BOPCOM 17/17: Summary of Discussion, BOPCOM 17/21: Fintechs and the Financial Side of Global Value Chains-The Changing Trade-Financing Environment, and BOPCOM 18/05: Towards a Framework for Measuring Trade Finance.
} 
breakdown is available on third party supply chain financing, and current data sources may not capture the great variety of traditional and new SCF instruments.

A single (satellite) table would provide a measure of the overall size of trade finance and overall market shares of banks versus Fintech to evaluate systemic risks. Knowledge about market shares of bank-intermediated and interfirm financing products can provide essential information about the resilience before, during, and after times of uncertainties. Comprehensive and reliable data on trade finance flows would facilitate an informed assessment of the market situation and the allow more targeted policy interventions.

A single data set would be more valuable than partial and patchwork information or costly ad hoc surveys. Several countries already have data sets in place that capture important segments of their trade finance markets. ${ }^{33}$ Some countries focus on domestic borrowing, while others concentrate on cross-border activities; off-balance sheet items of banks are generally excluded, and open account relationships in form of trade credits are disseminated as part of the balance of payments/international investment positions, but with serious flaws as discussed above.

To fill the data gap during the latest global financial crisis, the IMF and the Bankers' Association for Finance and Trade (BAFT) conducted four ad hoc surveys of banks between 2008 and 2010 on volume, prices, and drivers of trade finance. ${ }^{34}$ The World Bank sponsored an exceptional bank and company survey in 14 developing countries in 2009. Regular surveys of banks' strategies and business outlooks for trade financing are funded by the International Chamber of Commerce. While these initiatives provide useful insights into broader trends or market segments, a single table that is comprehensive in terms of coverage, standardized terminology, and instrumentation, would provide more systematic data over time.

\section{The Indicators of the Satellite Table on Trade Finance}

The proposed table is modelled on one of the templates of institutional sector accounts showing the liabilities of one sector as assets of the other sector (Table 1). The term satellite table refers to the standard terminology used in the various macroeconomic manuals. The table shows side-by-side cross-border and domestic finance relationships, and from external sector statistics, items covered under different functional categories. Two novel features of the table are the inclusion of contingent accounts payable and receivable that are off-balance sheet and memo-items ${ }^{35}$ that capture country-specific information on

\footnotetext{
${ }^{33}$ See BIS (2014).

${ }^{34}$ Asmundson, I., Dorsey, et al. Trade and Trade Finance in the 2008-09 Financial Crisis. IMF WP/11/16 https://iccwbo.org/publication/global-survey-2018-securing-future-growth/: 251 banks participated in the 2018 Global Survey, from 91 countries.

${ }^{35}$ Similar to the IMF Data Template on International Reserves and Foreign Currency. Washington D.C., 2016.
} 
complementary support programs in place. Table 1 shows the resident sectors liabilities visà-vis the resident (domestic) and nonresident (cross-border) sectors (their assets) by instrument. The mirror table would show the asset side. Table 2 shows the derived accounting entries for the various instruments (see Annex I) in the books of the supplier, buyer, and financial intermediary.

\section{The Satellite Table (Table 1) covers the three broad categories of trade finance instruments:}

a. Open-account inter/intra-firm trade finance comprising trade credits and advances

\section{b. Supply chain financing and other working capital-related financing comprising the} three main categories of SCF based on the various instruments of this groups (see Annex I):

i. Payables Finance where the supplier exchanges its claim on the buyer for a deposit with the financial intermediary. Instruments include Receivables Discounting, Forfaiting, and Factoring;

ii. Receivables Finance where the buyer's creditworthiness allows the supplier to receive an early discounted payment for the accounts receivable; the early financing is for 100 percent of the receivables less a discount. The buyer will pay the due amount directly to the financial intermediary;

iii. Loan/Advance against Receivables where the financial intermediary provides advances or loans to suppliers that are collateralized with future or current receivables.

\section{c. Traditional bank-intermediated instruments encompass different types of letters of} credit and are off-balance sheet until the conditions are met and the change of ownership established. ${ }^{36}$

d. Memo item on the role of private and public export credit agencies in a country could provide useful information on existing programs that are in place, for instance, to provide short-term lending of working capital, credit lines or credit guarantees for specific market segments, as well as to support regional trade or supply chain operations.

\footnotetext{
${ }^{36}$ Double-counting needs to be avoided for "loans backed by letters of credit or other trade-related documentation" (see MFSMCG paragraph 4.114).
} 


\section{Table 1. Proposed Satellite Table of Comprehensive Trade Financing}

(here: Liabilities of the Resident Sectors)

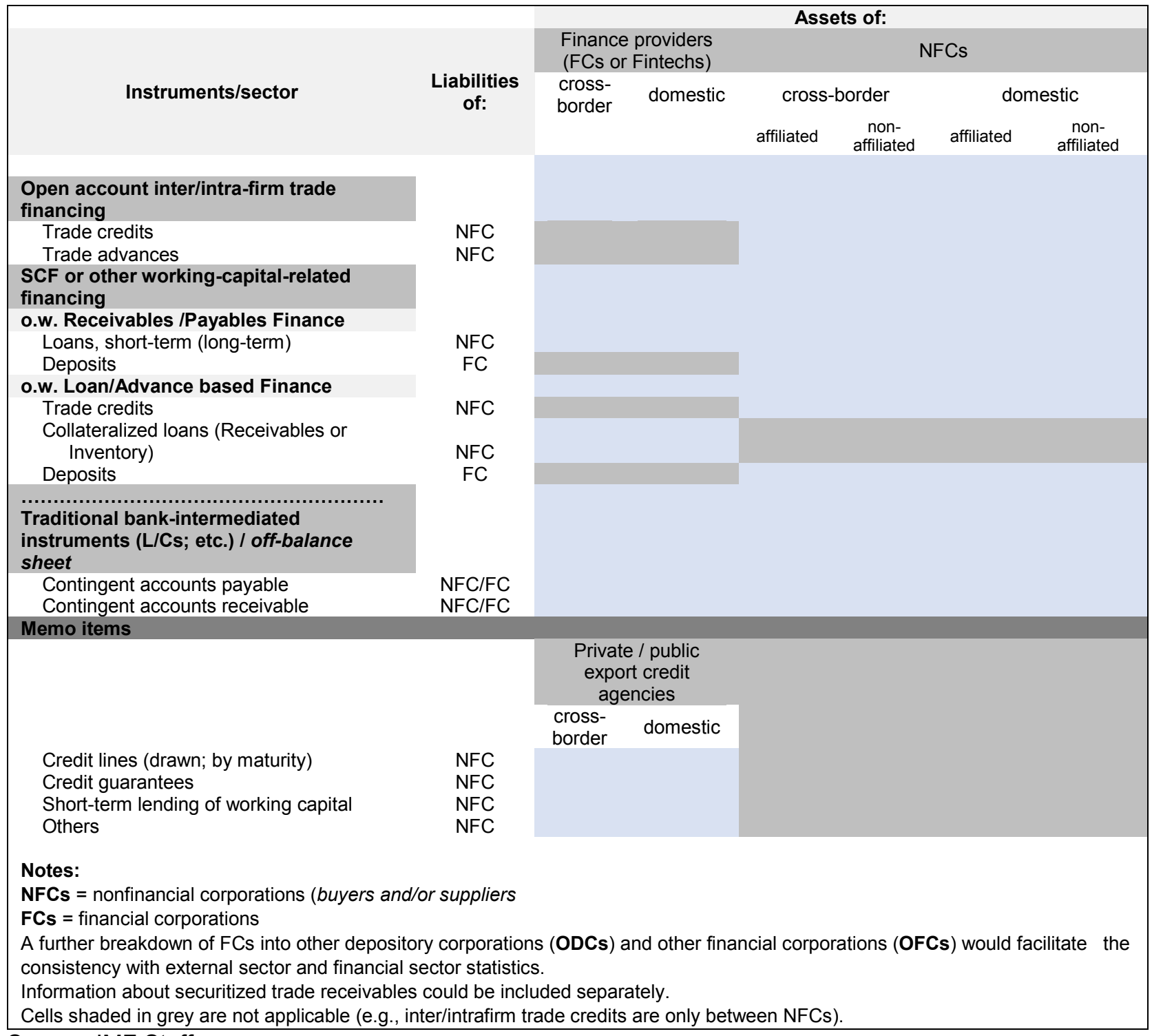

Source: IMF Staff.

\section{Comprehensive and efficient data collection comes with challenges to avoid omissions}

and/or double counting. One way to capture open account trade credits is to collect the data directly from NFCs. However, if, for instance, the supplier sells the claim embedded in the trade credit outright to a financial intermediary (Payables Finance), the instrument would be extinguished in the books of the supplier, but not in the books of the buyer. The trade credit asset is then in the financial intermediary's books. Suppliers can also sell only parts of the outstanding claims. Additionally, the data could be sourced to a large extent from financial intermediaries - this could include off-balance sheet data on $\mathrm{L} / \mathrm{Cs}$ as indicators of future trade. Further, this could include all SCF intermediation as well as direct loans and advances to suppliers/buyers to finance supply chain-related working capital. Overall, the data 
compilation will require a close collaboration between the statistical agencies of a country and should be in accordance with international standards.

Table 2. Derived Accounting for the Instruments of Finance Trade

\begin{tabular}{|c|c|c|c|c|c|c|}
\hline \multirow[b]{3}{*}{$\begin{array}{l}\text { A. Open account inter/ intrafirm } \\
\text { trade financing }\end{array}$} & \multicolumn{2}{|c|}{ SUPPLIER } & \multicolumn{2}{|c|}{ BUYER } & \multicolumn{2}{|c|}{ FINANCIAL INTERMEDIARY } \\
\hline & ASSET & LIABILITIES & ASSET: N/A & LIABILITIES & ASSET & LIABILITIES \\
\hline & trade credit & & & trade credit & & \\
\hline $\begin{array}{l}\text { B. Supply Chain Financing and } \\
\text { other working capital-related } \\
\text { financing }{ }^{1} \\
\text { (i) Receivables Finance (supplier-led) } \\
\text { (ii) Payables Finance (buyer-led) }\end{array}$ & $\begin{array}{c}\text { open account } \\
\text { trade credit asset } \\
\text { w/Buyer exchanged } \\
\text { for deposit } \\
\text { (working capital) } \\
\text { from } \mathrm{FI}^{2}\end{array}$ & & & $\begin{array}{c}\text { open account trade } \\
\text { credit liability to } \\
\text { Supplier, possibly } \\
\text { exchanged for } \\
\text { liability directly to } \\
\mathrm{Fl}^{2,3}\end{array}$ & $\begin{array}{c}\text { future payment } \\
\text { obligation (short- } \\
\text { term loan) from } \\
\text { Supplier (or directly } \\
\text { from Buyer) to } \mathrm{Fl}^{4}\end{array}$ & deposit Supplier \\
\hline (iii) Loan/Advance based Finance & $\begin{array}{l}\text { (i) open account } \\
\text { trade credit } \\
\text { w/Buyer } \\
\text { (ii) deposit } \\
\text { (working capital) } \\
\text { from FI }\end{array}$ & $\begin{array}{c}\text { trade-receivables } \\
\text { (collateralized } \\
\text { loan) }\end{array}$ & & $\begin{array}{l}\text { open account trade } \\
\text { credit w/Supplier }\end{array}$ & $\begin{array}{c}\text { trade-receivables } \\
\text { (collateralized } \\
\text { loan) }\end{array}$ & deposit Supplier \\
\hline $\begin{array}{l}\text { C.Traditional bank-intermediated } \\
\text { Instruments }\end{array}$ & $\begin{array}{c}\text { contingent } \\
\text { payment from FI }\end{array}$ & & & $\begin{array}{c}\text { contingent } \\
\text { payment to } \mathrm{FI}\end{array}$ & $\begin{array}{l}\text { contingent } \\
\text { payment from } \\
\text { Buyer }\end{array}$ & $\begin{array}{l}\text { contingent } \\
\text { payment to } \\
\text { Supplier }\end{array}$ \\
\hline
\end{tabular}

Source: IMF Staff.

\section{Conclusion}

Existing macroeconomic datasets do not adequately capture the large and growing trade finance market. This paper proposes a template to build a global new dataset of the main instruments and institutions comprising the trade finance market. The proposed table is consistent with macroeconomic statistical methodology, notably the 2008 SNA, BPM6, and $M F S M$. However, it proposes additional instruments and further breakdowns of the institutions.

This paper proposes a satellite Table of Comprehensive Trade Financing. The table was presented to the BOPCOM and during the 2018 meeting, members agreed on the analytical usefulness of a framework for collecting and disseminating data on trade finance. The data requirements for a comprehensive picture of trade finance are consistent but go beyond external sector statistics to include e.g., monetary and financial statistics, business statistics, and off-balance sheet data. Data collection would entail joint efforts of many agencies. There 
are also some conceptual issues of combining contingent trade finance (e.g., letters of credit) with existing instruments (e.g., trade credits, loans).

Going forward, pilot tests can identify the most effective way to bring the data together. Pilot countries from will review the data availability in their countries, discuss data collection with a small sample of relevant companies, and provide suggestions on possible changes or refinements of the table during the 2019 BOPCOM meeting. The data collection may result in a hybrid system combining existing and new data sources. Existing surveys may need more detailed reporting instructions on the instruments, and, if resources allow, separate surveys can specifically target companies that are part of supply chains and active in the import/export business. A substantive part of the information could be gathered from trade finance departments of banks. A breakdown of financing into "between related and between unrelated at arms-length buyers and suppliers would be of particular analytical interest. A stand-alone comprehensive table can offer overall insights on different country and regional patterns based on where an economy or region operates within global supply chains. 


\section{REFERENCES}

Accenture. "Mind the Gap - Addressing Challenges to Fintech Adoption.” 2018.

African Development Bank. Trade Finance in Africa: Overcoming Challenges. Cote d'Ivoire. 2017.

Asmundson, I., T. Dorsey, A. Khachatryan, I. Niculea, and M. Saito. "Trade and Trade Finance in the 2008-09 Financial Crisis.” Working Paper No. 11/16, International Monetary Fund, Washington D.C. 2011.

Bank of International Settlements (BIS). "Trade Finance: Developments and Issues" Committee on the Global Financial System Papers No. 50. 2014

Blancher, N., M. Appendino, A. Bibolov, A. Fouejieu, J. Li, A. Ndoye, A. Panagiotakopoulou, W. Shi, and T. Sydorenko. "Financial Inclusion of Small and Medium-Sized Enterprises in the Middle East and Central Asia." Departmental Paper Series, International Monetary Fund, Washington D.C. 2019.

Boddin, D. “The Role of Newly Industrialized Economies in Global Value Chains." Working Paper No. 16/207, International Monetary Fund, Washington D.C. 2016.

Brandi, C., and B. Schmitz. "Financing Global Development: The Potential of Trade Finance." German Development Institute, Germany. 2015. https://www.diegdi.de/en/briefing-paper/article/financing-global-development-the-potential-of-tradefinance.

Chaffour, J.P. and M. Malouche (Eds). "Trade Finance during the Great Trade Collapse: Key Takeaways.” The World Bank. 2011.

Financial Stability Board (FSB). FinTech Credit: Market Structure, Business Models and Financial Stability Implications. 2017.

G20 Trade Finance Experts Group. April Report Canada-Korea Chair's Recommendations for Finance Ministers. 2010. G20 Trade Finance Experts Group April Report Canada-Korea Chair's Recommendations for Finance Ministers.

G20 Trade Ministers Meeting Statement, July 9-10, 2016. Shanghai. https://www.wto.org/english/news e/news16_e/dgra_09jul16 e.pdf.

Global Supply Chain Finance Forum. Standard Definitions for Techniques of Supply Chain Finance. 2019. www.supplychainfinanceforum.org. 
He, D., R. Leckow, V. Haksar, T. Mancini-Griffoli, M. Kashima, N. Jenkinson, T. Khiaonarong, C. Rochon, and H. Tourpe. "Fintech and Financial Services: Initial Considerations." Staff Discussion Note 17/05, International Monetary Fund, Washington, DC. 2017

International Monetary Fund. Balance of Payments and International Investment Position Manual $\sigma^{\text {th }}$ Edition, footnote to paragraph 5.72, and paragraphs 6.9-6.10. Washington D.C. 2009.

_. Data Template on International Reserves and Foreign Currency Washington D.C., 2016.

- "Further External Debt Accounting Principles." In External Debt Statistics: Guide for Compilers and Users, Chapter 6. Washington D.C. 2014. http://www.tffs.org/pdf/edsg/ft2014.pdf

—. Government Finance Statistics Manual 2014: Manual. Washington, D.C., 2014.

-. Monetary and Financial Statistics Manual and Compilation Guide. Washington D.C., 2016.

International Monetary Fund Balance of Payments Committee (BOPCOM). BOPCOM 18/05: Towards a Framework for Measuring Trade Finance.

"Fintechs and the Financial Side of Global Value Chains - The Changing Trade-Financing Environment.” BOPCOM 17/21 Meeting 2017 Paper, Paris, France. 2017a

—.17/17 Meeting 2017, Summary of Discussion.” Paris, France. $2017 \mathrm{~b}$.

- Annual Report; paragraph 9. Washington D.C. 2016.

International Chamber of Commerce. Annual Global Surveys on Trade Finance (2016-2018). 2018.

—. 2017 Rethinking Trade and Finance. Paris, France. 2017.

Jain, J., G. Agarwal, G.S. Dangayach, and S. Banerjee. "Supply Chain Management: Literature Review and Some Issues." Journal of Studies on Manufacturing 10, no. 1 (January 16, 2010): 11-25. Accessed May 15, 2019. 
The Marco Polo Trade Finance Initiative. https://www.marcopolo.finance. Accessed May 15, 2019.

ModulTrade. Whitepaper - Democratizing global trade with Blockchain Technology. 2017. https://modultrade.io.

Niepmann, F. and T. Schmidt-Eisenlohr. "Banks in International Trade Finance: Evidence from the U.S.” Federal Reserve Bank of New York Staff Report no. 633. 2013.

PrimeRevenue. What is Dynamic Discounting? https://primerevenue.com/what-is-dynamicdiscounting/. Accessed May 10, 2019.

PrimeRevenue. "Supply Chain Finance 101" What is Supply Chain Finance? https://primerevenue.com/what-is-supply-chain-finance/ Accessed May 10, 2019

Roger, D., R. Leuschner, T. Y. Choi. "The Rise of FinTech in Supply Chains." Harvard Business Review, June 22, 2016. https://hbr.org/2016/06/the-rise-of-fintechin-supply-chains

Sheffi, Y. Lessons from a Crisis. Building Strength from Supply Chain Interdependence. 2017. https://c2fo.com/resources/enterprise/lessons-crisis-yossisheffi/.

TradeIX. "Rewiring Trade and Working Capital Finance." https://tradeix.com. Accessed May 10, 2019.

United Nations. System of National Accounts 2008. 2009.

World Economic Forum. 2015. The Future of FinTech: A Paradigm Shift in Small Business

World Trade Organization (WTO). 2017. Trade Finance. https://www.wto.org/english/thewto_e/coher_e/tr_finance_e.htm Apr 03, 2017. Accessed May 15, 2018. 


\section{Annex I. New Supply Chain Finance (SCF) Instruments in More Detail}

This annex provides further guidance for data compilers on the new instruments used for trade finance. It is based on suggested terminology and grouping by the Global Supply Chain Finance Forum. ${ }^{37}$

\section{SCF Definition Established by the GSCF Forum}

Supply Chain Finance is defined as the use of financing and risk mitigation practices and techniques to optimize the management of the working capital and liquidity invested in supply chain processes and transactions.

SCF is typically applied to open account trade and is triggered by supply chain events. Visibility of underlying trade flows by the finance provider(s) is a necessary component of such financing arrangements which can be enabled by a technology platform. [...]

[The buyers and sellers] often have objectives to improve supply chain stability, liquidity, financial performance, risk management, and balance sheet efficiency. SCF is not a static concept but is an evolving set of practices.

\section{Accounts Receivable Centric SCF Category}

Accounts or trade receivables refer to the outstanding invoices that a supplier has vis-à-vis the buyer of its goods and services. Receivables are recorded separately on the balance sheet as short-term claims. Using a receivables purchase program, the supplier sells all or parts of these outstanding claims to a financial intermediary or SCF service provider which takes full legal and economic ownership (and not just a security interest in the collateral); in return, it provides the supplier with working capital in form of advance payments less the financial service charge (called discount), reducing the days sales outstanding (DSO) and providing much needed liquidity the company can work with.

The following three techniques on the market are seller (supplier)-led programs.

(1) Receivables Discounting (Annex Figure 1) allows suppliers with outstanding short-term invoices mostly vis-à-vis multiple buyers to sell their receivables to a financial provider at a discount. This instrument is usually reserved to investment-grade suppliers that have a minimum credit rating. This allows the finance provider to offer this program on a full or partly "without recourse" 38 basis; i.e., the supplier can remove the accounts receivables

\footnotetext{
37 The GSCFF notes that "Definitions featured in the publication will be useful to finance providers, corporates, commercial and SME clients, investors, regulators, legal practitioners, information technology and infrastructure providers, as well as other trade finance related communities." http://supplychainfinanceforum.org/.

${ }^{38}$ Without recourse means: without subsequent liability. As a legal term, it signifies that the finance provider (and not the seller) of an asset is assuming the risk of non-payment of the asset.
} 
completely or partly from its balance sheet, and the finance provider bears the risk in case the buyers fail to perform their payments. A trade credit insurance can limit the risk exposure of the finance provider. This financing transaction between the supplier and a finance provider can be made with or without the knowledge of the buyers; and depending on the situation in some cases, the buyers may be asked to validate their accounts payables.

\section{Annex Figure 1. Receivables Discounting}

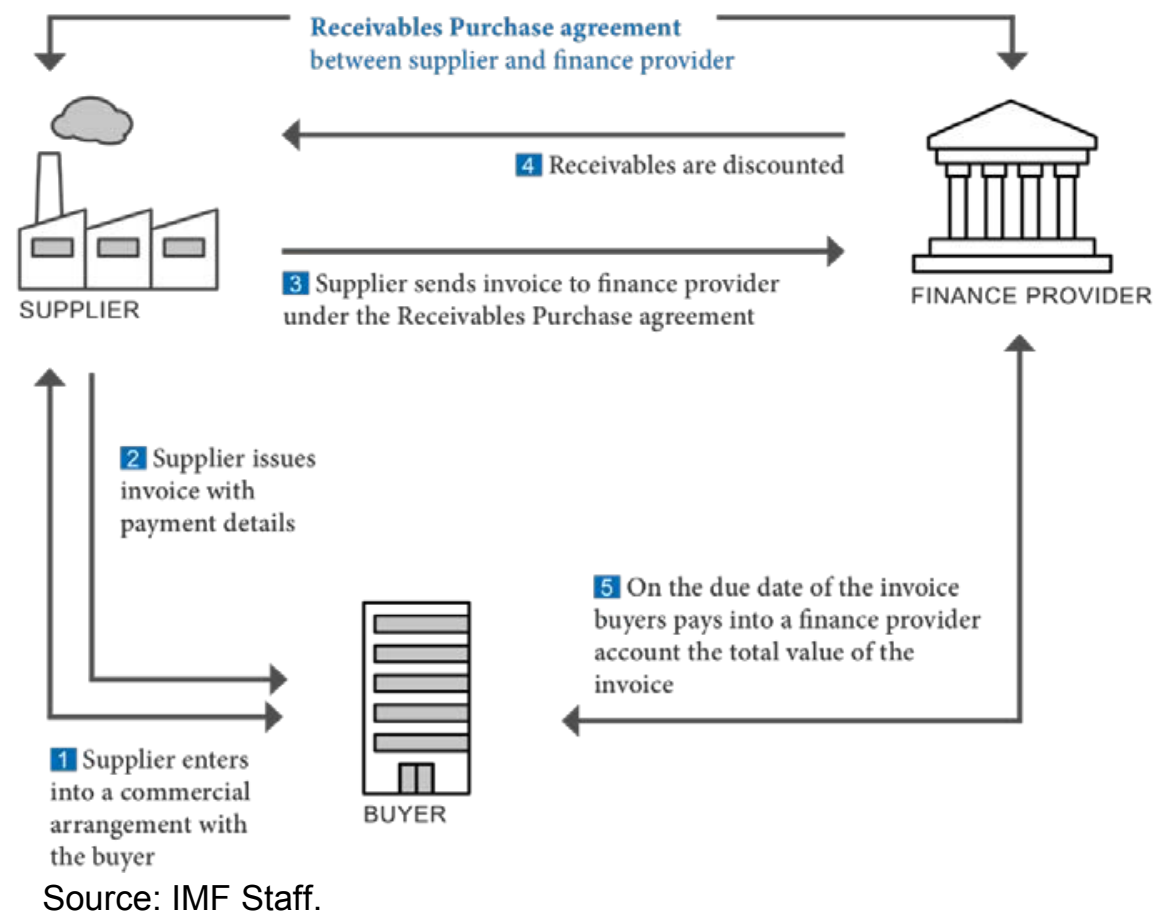

At maturity, the buyers pay the amounts of the invoices into the bank account (i) of the supplier, with limited access rights of the supplier; (ii) of the finance provider (the finance provider does not have to be a bank); or (iii) of the supplier without restriction, adding an additional element of risk for the finance provider.

The buyer benefits from extended credit terms in a stable supply chain environment. The supplier profits from increased short-term liquidity. And the finance provider provides services in a relatively stable non-speculative financial environment.

(2) Forfaiting (Annex Figure 2) is an export-oriented form of supply chain finance where a forfaiter (finance provider) purchases from the supplier, without recourse, future payment obligations and trades these as negotiable debt instruments in the form of bills of exchange, promissory notes, or $\mathbf{L} / \mathbf{C s}$ on the secondary forfaiting market. These payment instruments are legally independent from the underlying trade and require a guarantee by a third party (normally the buyer's bank). 


\section{Annex Figure 2. Forfaiting}

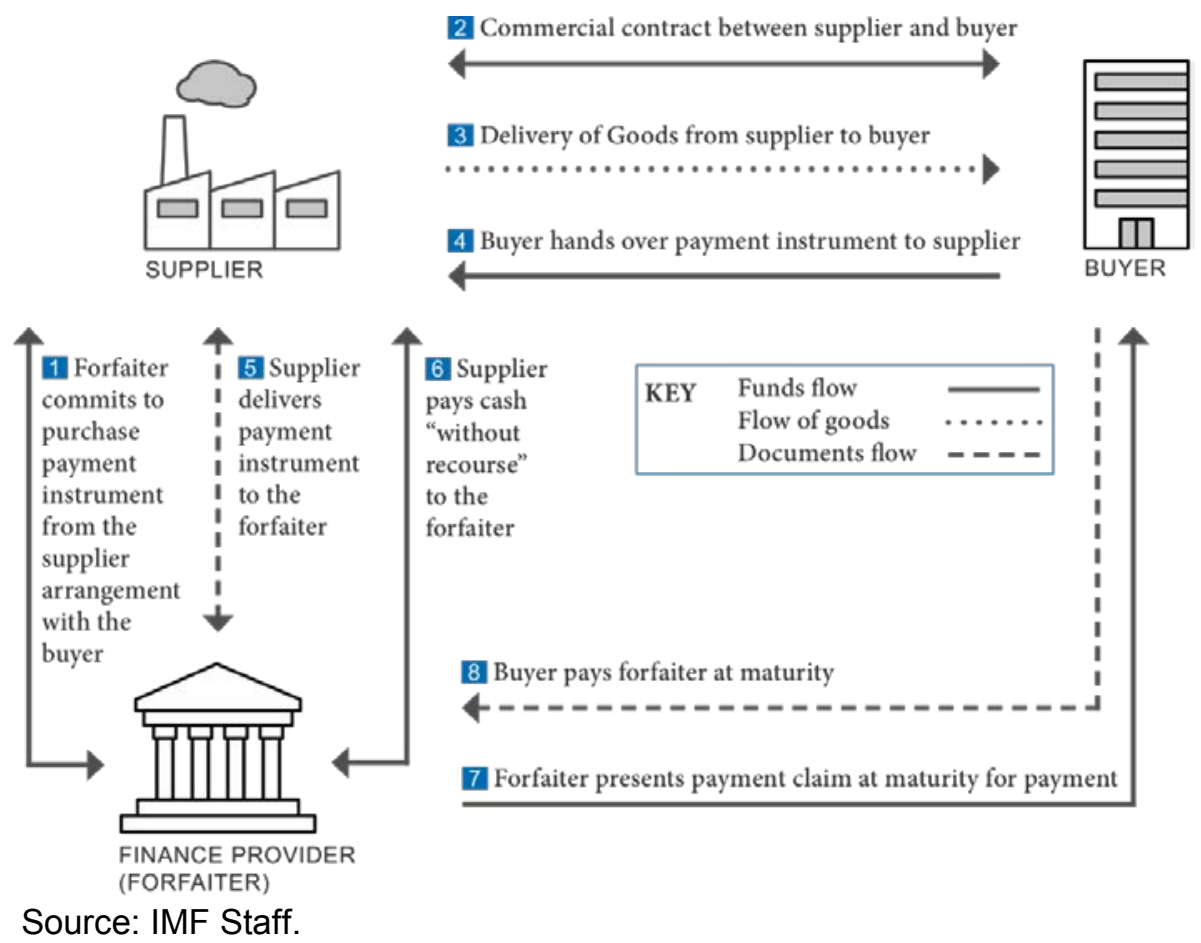

In the secondary market, forfaiters deal with financial investors. In the primary market, the supplier approaches the forfaiter before signing the contract with the buyer. The buyer obtains a bank guarantee and provides the documents that the supplier requires to complete the forfaiting. After receiving 100 percent cash payment against delivery of the payment (debt) obligation, the supplier has no further interest in the transaction, because the forfaiter must collect the future payments plus forfaiting costs (included in the invoice price) via the guarantor from the buyer. Forfaiting involves mostly medium-to-long-term maturities, and is most commonly used in large, international sales of capital goods.

Forfaiting helps suppliers trade with buyers of countries with high levels of risks, and obtain a competitive advantage by being able to extend credit terms to their customers. While the without-recourse-sale eliminates all risks for the supplier, the forfaiter charges for credit risks as well as for covering the political, commercial, and transfer risk related to the importing country, which is also linked to the length of the loan, the currency of transaction, and the repayment structure. The costs are higher than commercial bank financing, but more cost effective than traditional trade finance tools. Forfaiting is only used in international trade financing.

(3) Factoring (Annex Figure 3) targets the domestic and international market, whereby the latter often includes two "factors," one in each country. The suppliers, often SMEs, receive around 80 percent of the invoice value from the factor as advance payment, and a remaining, but discounted, value when payment is due by the buyer. The fees and discounts are borne by 
the supplier in return for the factor's services of advancing funds and managing the collecting of the receivables from the buyer. Because factoring is available with and without recourse, depending on the circumstances in the market, the factoring institution may add a credit insurance. Factoring provides suppliers with working capital, albeit discounted, allowing them to continue trading, while the factor receives margins from rendering the service.

\section{Annex Figure 3. Factoring}

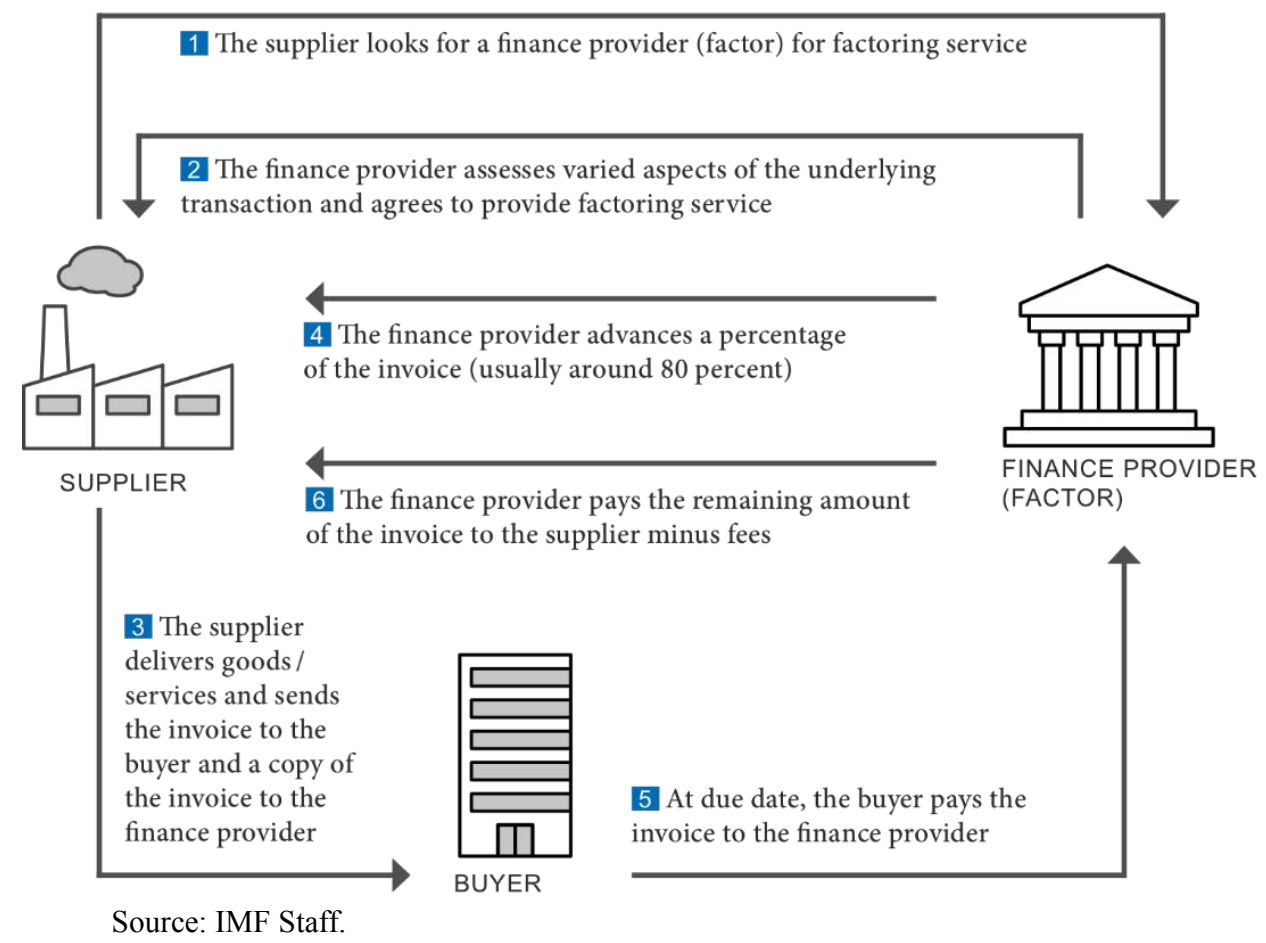

Asset-based financing linked to the physical supply chain is not a new concept. There are a variety of traditional techniques for accessing finance both pre- and post-shipment. However, traditional factoring is often not fit for purpose for small businesses, as it typically entails long-term, complex contracts with fixed volumes. ${ }^{39}$ The innovations with SCF are the automated business processes and e-invoicing tools that are based on a central technology platform simultaneously accessed by buyers, sellers, and SCF providers. ${ }^{40}$

\footnotetext{
${ }^{39}$ World Economic Forum. 2015.

${ }^{40}$ This overall elevated collaboration between the parties to the financial transaction and the visibility of the underlying trade flows may be the reason why SCF outperforms traditional financing. Additionally, SCF is based on buyer-led financing (financing provided by large buyers to their smaller suppliers) rather than supplier-led financing. Once the supplier has agreed, the buyer approves the invoice, and a cascade of processes takes place on the SCF provider's platform.
} 
(4) Reverse Factoring, also known as Approved Payables Finance, ${ }^{41}$ is a buyer-led and arranged financing program for designated suppliers in the supply chain (Annex Figure 4). The buyer's creditworthiness allows the supplier to receive an early discounted payment for the accounts receivables, typically without recourse. The buyer will later pay the due amount directly to the finance provider. Buyers can be large and medium-sized and at times even near non-investment grade (given, an established buyer-finance provider relationship exists); however, buyers only arrange the financing, they are not part of the financing transaction. As with previous cases, the assets are changing ownership from the suppliers to the financial intermediary. The early financing is for 100 percent of the receivables less a discount, which is lower than with conventional trade financing. As before, the buyer receives an extended term for payment in a secured supply chain environment.

\section{Annex Figure 4. Approved Payables Finance}

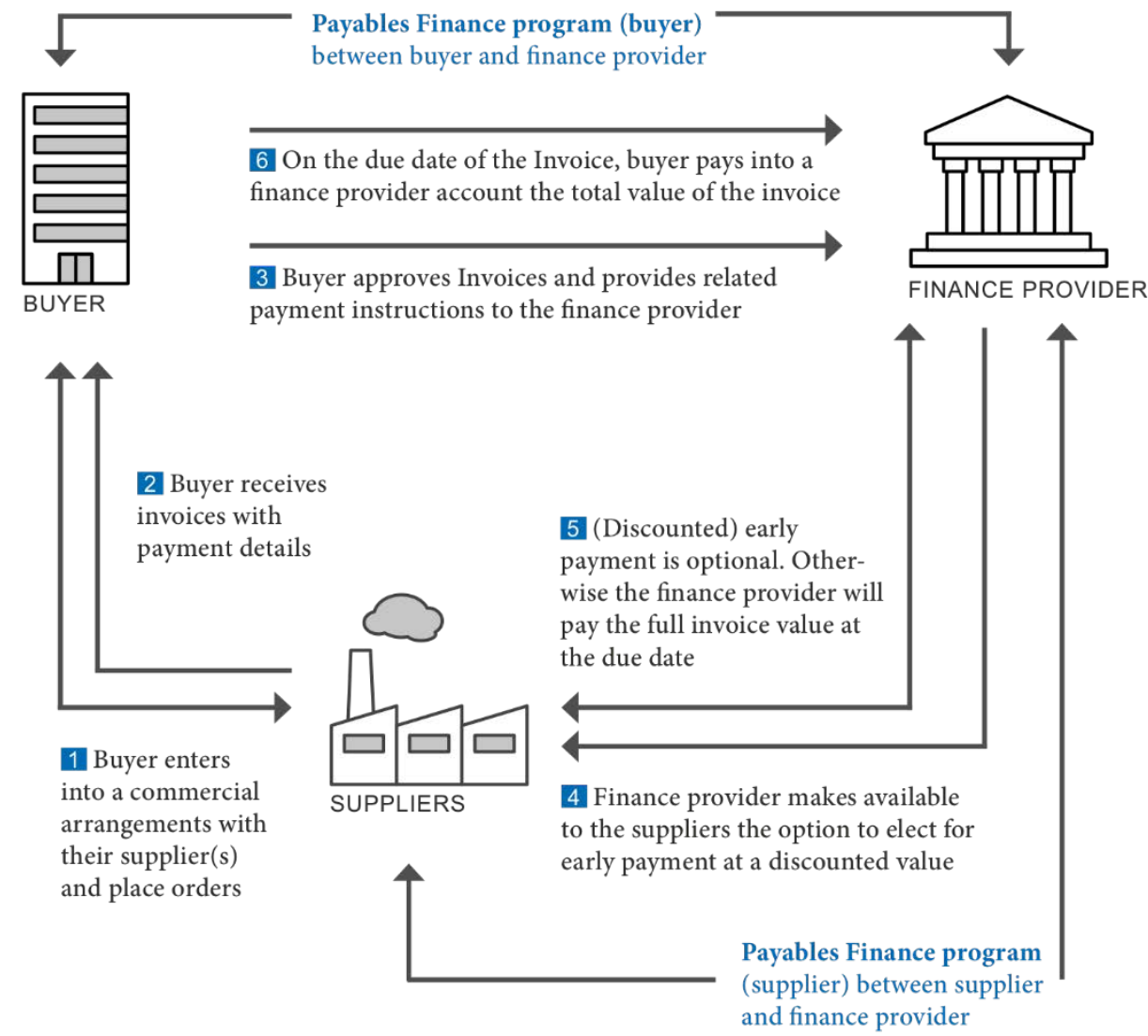

Source: IMF Staff.

(4a) Dynamic Discounting is a variation to (4), where buyers use their own funds in to decide how and when to pay their suppliers in exchange for a discount on the purchased goods. The earlier the payment, the larger the discount. The buyers can use their own access

\footnotetext{
41 This SCF program currently has various names; most commonly, "reverse factoring." There may be slight differences in the execution of the programs.
} 
liquidity to generate additional income, while the supplier can optimize the days outstanding and the working capital.

Dynamic discounting is a typical example where Fintech companies ${ }^{42}$ entered the market as providers of web-based platforms that allow both parties to upload, view, and approve invoices for early payment. For the buyers, there is no additional cost; the suppliers are charged a fee once they request early payment of the approved invoices.

Overall, in this category of Accounts Receivable Financing the financial claims move from the suppliers' books to the SCF providers (the service provider or directly to the finance provider); hence, no new financial debt is created in the books of the suppliers for receiving early payment, in return for new liquidity. On the creditor side, SCF programs ${ }^{43}$ can be selffunded by the buyers, or composed of a mixed program where financing is shared by the buyers, capital markets, and financial institutions.

\section{Loan/Advance based SCF category}

The second SCF category is based on loans and advances, where financing is usually provided in return for rights to a collateral, and the loan is recorded as a liability in the beneficiaries' balance sheet.

(5) The new edge to an existing instrument called Distributor Financing (or Channel Financing) is that large MNCs (as suppliers) are using this instrument increasingly for expanding into emerging markets. The MNCs support the financing of a geographicallyimportant (network of) established distributors against their retail inventory, and the distributors repay their debt once the inventory is sold. Although the finance provider (e.g., local bank) is providing the funds and taking on the risks, often MNCs subsidize the financing by absorbing part of the interest margins or engaging in other forms of risk-sharing arrangements, and through reputational support. MNCs directly benefit from their suppliers' sales of goods to these distributors (buyers), and indirectly, because a sound supply chain allows end-customers to profit from products that can be delivered without delay. Distributor Financing has limited impact on MNCs balance sheets compared to foreign direct investment. Therefore, Distributor Financing can be an alternative to direct investment and preferred to establishing inventory-carrying subsidiaries abroad. Through the engagement of the MNCs, distributors profit from better loan prices and bridging liquidity gaps. The collateral for the finance providers is usually an assignment of rights over the inventory.

\footnotetext{
${ }^{42}$ For instance: PrimeRevenue. What is Dynamic Discounting? https://primerevenue.com/what-is-dynamicdiscounting/.

${ }^{43}$ For instance: PrimeRevenue. "Supply Chain Finance 101 What is Supply Chain Finance?" https://primerevenue.com/what-is-supply-chain-finance/.
} 
(6) With Loan or Advance against Receivables (Annex Figure 5), the financial intermediary provides advances or loans to suppliers that are collateralized with future or current receivables, while collateralization may be formalized or accepted informally. The suppliers repay the loans upon maturity and interest on an accrual basis.

\section{Annex Figure 5. Loan or Advance Against Receivables}

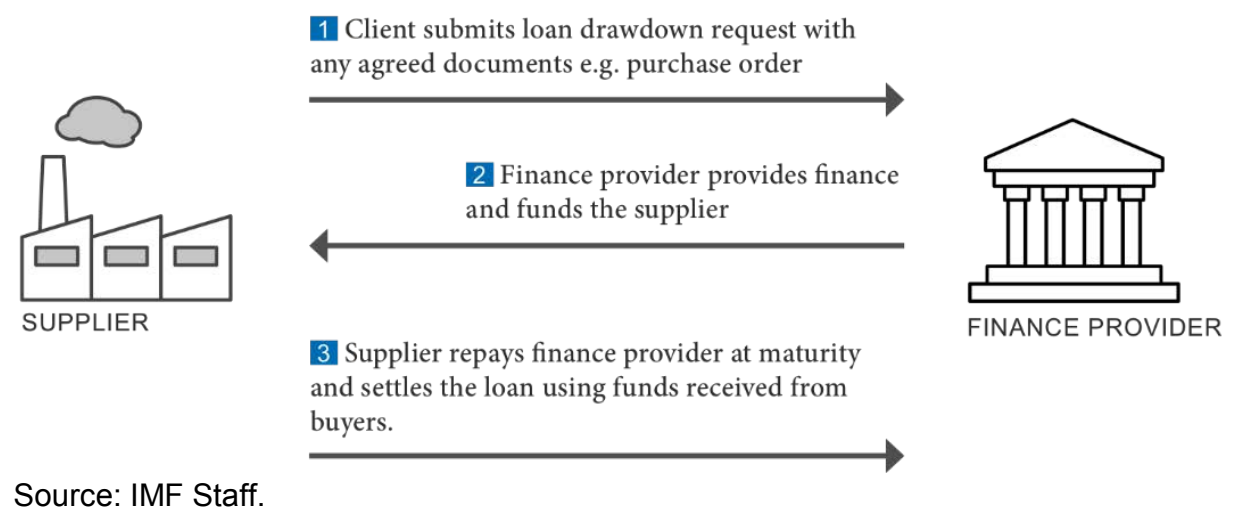

(7) Loan or Advance against Inventory (Annex Figure 6) is an asset-based financing instrument in form of a credit line for suppliers and buyers along the physical supply chain to raise funds "instead of locking unused value inside a warehouse." The finance providers obtain title over the goods as collateral and utilize on-site inspections and property insurance for risk mitigation. Furthermore, finance providers base their lending on the inventory's appraised value, which is usually lower than the market value, and finance about 80 percent of this amount. For finished goods or work-in-progress, finance providers may also require purchase orders (on behalf of the buyers) or purchase contracts (on behalf of an endcustomer). The transactions are settled regularly at the time inventory is used for production or sold off to customers. Although inventory financing is more expensive than other SCF instruments, for a certain market, it still provides advantageous terms, such as the ability to accumulate inventory and optimize working capital for lower rates than conventional bank financing. 


\section{Annex Figure 6. Loan/Advance Against Inventory}

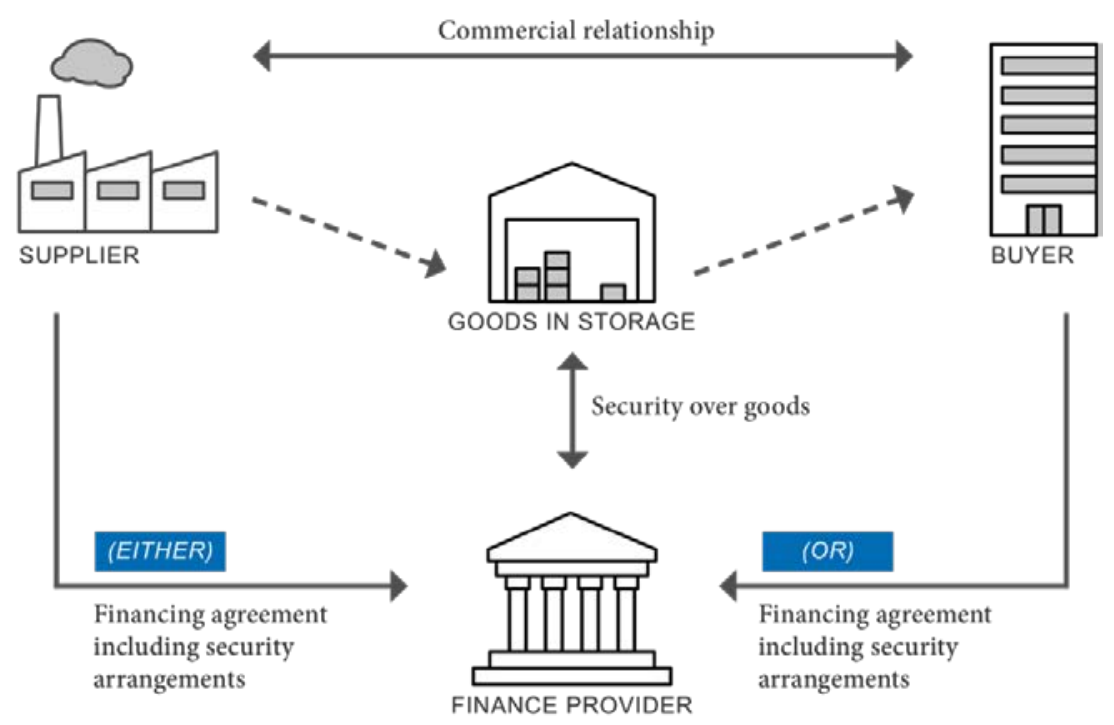

Source: IMF Staff.

(7a) Financing of "toll manufacturing" of the inventory is a variation of (7); toll manufacturing is what the SNA calls "manufacturing services on physical inputs owned by others" (as opposed to contract manufacturing, where the manufacturer owns and provides the raw materials).

(7b) Inventory repurchase (repo) agreement or buy-back agreement is a special case of inventory financing when the buyer/supplier temporarily "sells" its inventory to a financing entity, and 'buys' it back after a predetermined time. What appears to be a sale and buy-back is in fact not recognized as a true sale by the accounting bodies. Therefore, the inventory stays on the balance sheet and the funds received are recorded as liability until the repurchase takes place within the pre-agreed upon period (usually 30, 60 or 90 days).

(8) Pre-Shipment Financing (sometimes called "Packing credit") is illustrated in Annex Figure 7). A manufacturer receives financial assistance for purchasing raw materials, processing, and packing the finished goods for exporting. Although the financial transaction is between the manufacturer and the finance provider, the creditworthiness and reliability of the buyer play a role in negotiations, and so does the manufacturer's reputation to perform and deliver. A prerequisite for granting the financing may often be (i) a specific kind of $\mathrm{L} / \mathrm{C}$ from the buyer and their bank or a confirmed and irrevocable purchase order (PO) for the export of goods; (ii) the documents relating to the raw materials may be pledged to the finance provider as collateral; and (iii) the granting of inspections to the finance provider during the manufacturing cycle. 


\section{Annex Figure 7. Pre-shipment Finance}

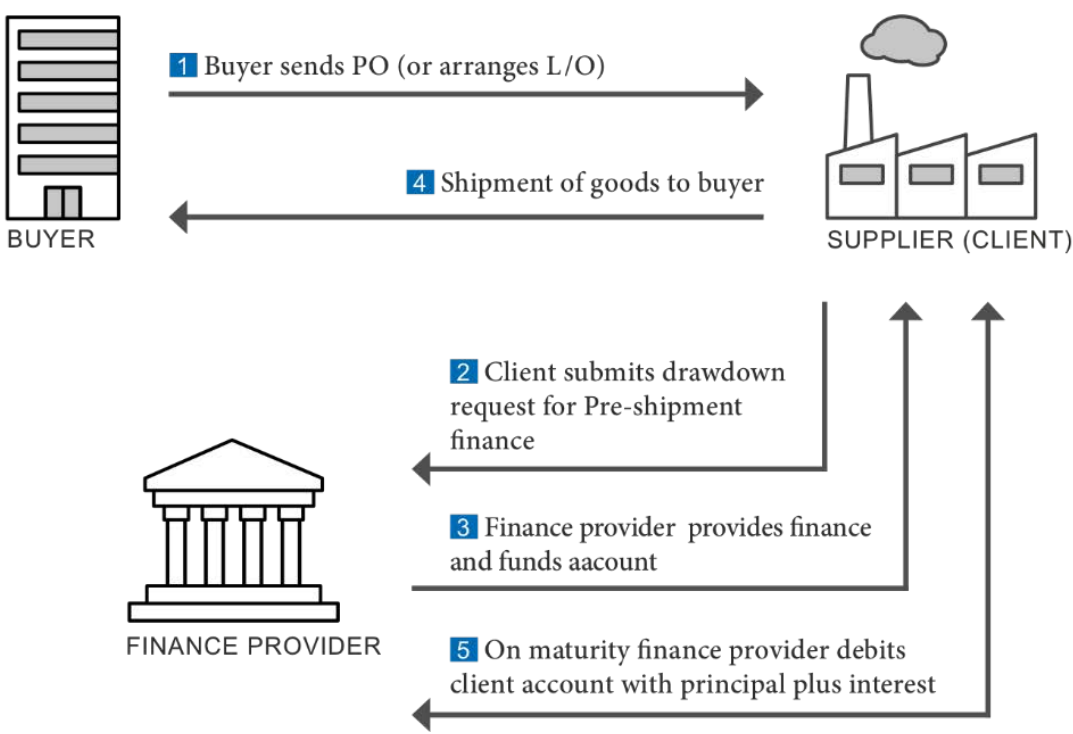

Source: IMF Staff. 